\title{
Utilization of $\mathrm{O}_{4}$ slant column density to derive aerosol layer height from a space-borne UV-visible hyperspectral sensor: sensitivity and case study
}

\author{
Sang Seo Park ${ }^{1, a}$, Jhoon Kim ${ }^{1}$, Hanlim Lee ${ }^{1,2}$, Omar Torres ${ }^{3}$, Kwang-Mog Lee ${ }^{4}$, and Sang Deok Lee \\ ${ }^{1}$ Department of Atmospheric Sciences, Yonsei University, Seoul, South Korea \\ ${ }^{2}$ Department of Spatial Information Engineering, Pukyong National University, Busan, South Korea \\ ${ }^{3}$ NASA Goddard Space Flight Center, Greenbelt, Maryland, USA \\ ${ }^{4}$ Department of Astronomy and Atmospheric Sciences, Kyungpook National University, Daegu, South Korea \\ ${ }^{5}$ National Institute of Environment Research, Ministry of Environment, Incheon, South Korea \\ anow at: Research Institute for Applied Mechanics, Kyushu University, Fukuoka, Japan
}

Correspondence to: Jhoon Kim (jkim2@yonsei.ac.kr)

Received: 24 October 2014 - Published in Atmos. Chem. Phys. Discuss.: 17 March 2015

Revised: 12 January 2016 - Accepted: 20 January 2016 - Published: 23 February 2016

\begin{abstract}
The sensitivities of oxygen-dimer $\left(\mathrm{O}_{4}\right)$ slant column densities (SCDs) to changes in aerosol layer height are investigated using the simulated radiances by a radiative transfer model, the linearized pseudo-spherical vector discrete ordinate radiative transfer (VLIDORT), and the differential optical absorption spectroscopy (DOAS) technique. The sensitivities of the $\mathrm{O} 4$ index $(\mathrm{O} 4 \mathrm{I})$, which is defined as dividing $\mathrm{O}_{4} \mathrm{SCD}$ by $10^{40}$ molecules ${ }^{2} \mathrm{~cm}^{-5}$, to aerosol types and optical properties are also evaluated and compared. Among the $\mathrm{O}_{4}$ absorption bands at 340, 360, 380, and $477 \mathrm{~nm}$, the $\mathrm{O}_{4}$ absorption band at $477 \mathrm{~nm}$ is found to be the most suitable to retrieve the aerosol effective height. However, the O4I at $477 \mathrm{~nm}$ is significantly influenced not only by the aerosol layer effective height but also by aerosol vertical profiles, optical properties including single scattering albedo (SSA), aerosol optical depth (AOD), particle size, and surface albedo. Overall, the error of the retrieved aerosol effective height is estimated to be 1276,846 , and $739 \mathrm{~m}$ for dust, non-absorbing, and absorbing aerosol, respectively, assuming knowledge on the aerosol vertical distribution shape. Using radiance data from the Ozone Monitoring Instrument (OMI), a new algorithm is developed to derive the aerosol effective height over East Asia after the determination of the aerosol type and AOD from the MODerate resolution Imaging Spectroradiometer (MODIS). About $80 \%$ of retrieved aerosol effective heights are within the error range of $1 \mathrm{~km}$
\end{abstract}

compared to those obtained from the Cloud-Aerosol Lidar with Orthogonal Polarization (CALIOP) measurements on thick aerosol layer cases.

\section{Introduction}

Aerosol is one of the key atmospheric constituents in understanding climate changes with its effects on direct and diffuse solar radiation (e.g., Haywood and Shine, 1995; Kaufman et al., 2002) and plays an important role in air quality near the surface (e.g., Watson et al., 1994; Prospero, 1999). For these reasons, observations from satellite remote sensing have been carried out to investigate aerosol properties at regional and global scale, including aerosol optical depth (AOD) (e.g., Curier et al., 2008; Levy et al., 2007; Torres et al., 2007; Ahn et al., 2014; Veefkind et al., 1999; Zhang et al., 2011), fine-mode fraction (FMF) or Ångström exponent (AE) (e.g., Jones and Christopher, 2007; Lee et al., 2010; Nakajima and Higurashi, 1998; Remer et al., 2008), single scattering albedo (SSA) (e.g., Dubovik et al., 2002; Levy et al., 2007; Jeong and Hsu, 2008; Torres et al., 1998, 2005, 2007; Jethva et al., 2014), and aerosol types (e.g., Higurashi and Nakajima, 2002; Kim et al., 2007; Lee et al., 2010). This information was further utilized to estimate radiative forcing of aerosol (e.g., Christopher et al., 2006; Chung et al., 
2005; Chou et al., 2002), to understand the mechanism of the changes to the cloud formation (Twomey et al., 1984; Albrecht, 1989; Jones et al., 1994), and to monitor air quality (e.g., Wang and Christopher, 2003; Hutchison et al., 2005).

Vertical profiles of atmospheric aerosols are affected by processes of formation, transport, and deposition and vary for different aerosol types over East Asia (Shimizu et al., 2004). Labonne et al. (2007) also reported that the layer top height of biomass burning aerosol ranged from 1.5 to $7 \mathrm{~km}$ in the wild fire regions. The information on the aerosol layer height is important, because the variation of the aerosol vertical distribution affects radiative processes in the atmosphere near the surface and trace gas retrieval for air mass factor calculation. Uncertainty in aerosol layer height also affects the accuracy of AOD and SSA retrieval algorithms that use near-UV observations (Torres et al., 1998, 2007; Jethva et al., 2014) and complicates the interpretation of the Aerosol Index (AI), a qualitative parameter commonly used to detect absorbing aerosols (Herman et al., 1997; Torres et al., 1998). In addition, there have been difficulties to estimate surface concentration of aerosol from AODs, because the information on aerosol vertical distribution is not readily available and even hard to predict from the state-of-the-art models due to its large variability. Although the Cloud-Aerosol Lidar with Orthogonal Polarization (CALIOP) has been successful and provided vertical profiles of aerosols, its spatial coverage was very limited with its measurement characteristics (Omar et al., 2009). Liu et al. (2005) showed that the particulate matter (PM) concentration estimated by the AOD from satellite observation accounted for only $48 \%$ of the measured surface PM, although their study reflected variations of the aerosol types and its hygroscopic growth in the algorithms. One of the essential factors to consider in estimating PM from AOD is the vertical structure of aerosols (e.g., Chu, 2006; Seo et al., 2015). Therefore, conventional aerosol products would benefit significantly with the development of robust algorithm to retrieve aerosol height using satellite data.

The differential optical absorption spectroscopy (DOAS) technique has been used widely to retrieve trace gas concentration both from ground-based (e.g., Platt, 1994; Platt and Stutz, 2008) and space-borne (e.g., Wagner et al., 2007, 2010) measurements. After the work of Platt (1994) to retrieve trace gas concentration by using DOAS, Wagner et al. (2004) suggested deriving atmospheric aerosol information from $\mathrm{O}_{4}$ measurement by using multi-axis differential optical absorption spectroscopy (MAX-DOAS). Friess et al. (2006) analyzed the model studies to calculate the achievable precision of the aerosol optical depth and vertical profile. In addition, several studies (e.g., Irie et al., 2009, 2011; Lee et al., 2009, 2011; Clémer et al., 2010; Li et al., 2010) provided aerosol profiles from ground-based hyperspectral measurements in UV and visible wavelength ranges on several ground sites. Wagner et al. (2010) investigated the sensitivity of various factors to the aerosol layer height using the data obtained from the SCanning Imaging Absorption spec-
troMeter for Atmospheric CHartographY (SCIAMACHY) on Envisat. The sensitivity of the Ring effect and the absorption by oxygen molecules $\left(\mathrm{O}_{2}\right)$ and its dimer $\left(\mathrm{O}_{4}\right)$ calculated by the DOAS method were examined to estimate aerosol properties including the layer height. Kokhanovsky and Rozanov (2010) estimated dust altitudes using the $\mathrm{O}_{2}$ A band between 760 and $765 \mathrm{~nm}$ after the determination of the dust optical depth. In addition, several previous studies also investigated estimation methods for aerosol height information by using hyperspectral measurement in the visible spectrum (e.g., Dubuisson et al., 2009; Koppers and Murtagh, 1997; Sanders and de Haan, 2013; Sanghavi et al., 2012; Wang et al., 2012). Because the surface signal is significantly smaller than the aerosol signal in the near-UV spectrum, these wavelength regions are useful to derive aerosol height information from space-borne measurements.

For Ozone Monitoring Instrument (OMI) measurement, the $\mathrm{O}_{4}$ band at $477 \mathrm{~nm}$ has been widely applied to estimate cloud information (e.g., Accarreta et al., 2004; Sneep et al., 2008). In particular, the cloud information retrieved by the $\mathrm{O}_{4}$ band at $477 \mathrm{~nm}$ was used to analyze the air mass factor with the consideration of aerosol optical effects for the $\mathrm{NO}_{2}$ column retrieval (e.g., Castellanos et al., 2015; Chimot et al., 2015; Lin et al., 2014, 2015). Although the $\mathrm{O}_{4}$ absorption band around $477 \mathrm{~nm}$ varies due to cloud existence, it can also be used for the aerosol optical parameter estimation. Veihelmann et al. (2007) posited that the $477 \mathrm{~nm}$ channel, a major $\mathrm{O}_{4}$ band, significantly adds to the degree of freedom for aerosol retrieval by using principal component analysis, and Dirksen et al. (2009) adopts the pressure information obtained from the $\mathrm{OMI} \mathrm{O}_{4}$ band to identify a plume height for aerosol transport cases.

In this study, the sensitivities of the $\mathrm{O}_{4}$ bands at 340, 360, 380 , and $477 \mathrm{~nm}$ to changes in aerosol layer height and its optical properties are estimated using simulated hyperspectral radiances, differently from the previous studies using the $\mathrm{O}_{2}$ A band observation (e.g., Kokhanovsky and Rozanov, 2010). We proposed an improved DOAS algorithm for the $\mathrm{O}_{4}$ absorption bands to retrieve aerosol height information from the $\mathrm{O}_{4}$ slant column densities (SCDs) based on the sensitivity studies. This new algorithm is applied to the $\mathrm{O}_{4} \mathrm{SCD}$ from the OMI to retrieve the aerosol effective height (AEH) for a real case over East Asia, including error estimates.

\section{Methods}

In general, scattering by aerosol at low altitudes leads to an increase in the length of the average light path (enhancement effect), while scattering at high altitudes causes a decrease in the length of the average light path (shielding effect) (Wagner et al., 2010). These two opposing effects change the estimated $\mathrm{O}_{4} \mathrm{SCD}$ values. Furthermore, the measured $\mathrm{O}_{4} \mathrm{SCD}$ is a function of wavelength, because the absorption and scattering by atmospheric molecules and aerosols have spectral de- 
pendence. Therefore, radiative transfer calculations are carried out to estimate the sensitivity of the $\mathrm{O}_{4} \mathrm{SCD}$ with respect to the change of atmospheric conditions. Details of the radiative transfer model (RTM) and input parameters to simulate radiance are discussed in Sect. 2.1. Analytical method of the DOAS to estimate the $\mathrm{O}_{4}$ is described in Sect. 2.2.

\subsection{Simulation of hyperspectral radiance}

Figure 1 shows the flowchart of the method to estimate the $\mathrm{O}_{4}$ SCD from the simulated radiance. Because the magnitude of the $\mathrm{O}_{4} \mathrm{SCD}$ values is too large to express the sensitivity results, this paper defines the $\mathrm{O}_{4}$ index $(\mathrm{O} 4 \mathrm{I})$ which divides $\mathrm{O}_{4} \mathrm{SCD}$ by $10^{40}$ molecules $^{2} \mathrm{~cm}^{-5}$. In order to investigate the sensitivities of the O4I at several bands in UV and visible wavelengths with respect to various aerosol properties, including AEHs, aerosol amounts, and aerosol types, the hyperspectral radiance is simulated using the linearized pseudo-spherical vector discrete ordinate radiative transfer (VLIDORT) model (Spurr, 2006). The VLIDORT model is based on the linearized discrete ordinate radiative transfer model (LIDORT) (Spurr et al., 2001; Spurr, 2002). This RTM is suitable for the off-nadir satellite viewing geometry of passive sensors since this model adopts the spherically curved atmosphere to reflect the pseudo-spherical direct-beam attenuation effect (Spurr et al., 2001). The model calculates the monochromatic radiance ranging from 300 to $500 \mathrm{~nm}$ with a spectral resolution of $0.1 \mathrm{~nm}$. The radiance spectrum is calculated with a $0.2 \mathrm{~nm}$ sampling resolution, applying a slit response function (SRF) given by a normalized Gaussian distribution with $0.6 \mathrm{~nm}$ as the full-width half maximum (FWHM).

\subsubsection{Aerosol properties}

The aerosol input parameters for the RTM are important in simulating the radiance spectra because aerosol optical properties determine scattering and absorption characteristics. The data from the Optical Properties of Aerosol and Cloud (OPAC) package (Hess et al., 1998) are used as aerosol parameters, which includes the spectral complex refractive indices and size distribution of aerosols to calculate SSA and phase function through the Mie calculations. The information of the aerosol parameters is not available at the UV wavelengths, since the AERONET observation provides the information of those aerosol parameters in the visible wavelength.

In terms of the aerosol types, water-soluble (WASO), mineral dust (MITR), and continental polluted (COPO) models are selected to simulate non-absorbing aerosol, mineral dust, and absorbing anthropogenic aerosol, respectively. The COPO is a combined type that includes both soot and WASO, which represents the pure black carbon and non-absorbing aerosols, respectively. The mixture of these two types adequately describes the fine-mode aerosol from anthropogenic pollution. The SSA is the largest for WASO and the smallest for COPO. In order to account for hygroscopic growth, the default relative humidity is assumed to be $80 \%$ (cf., HolzerPopp and Schroedter-Homscheidt, 2004).

\subsubsection{Aerosol vertical distribution}

In this present study, "aerosol height" refers to aerosol effective height (AEH), defined as the peak height in Gaussian distribution. According to Hayasaka et al. (2007), however, the aerosol extinction coefficient was found to exponentially decrease with altitude over East Asia based on the groundbased lidar observation data during the Atmospheric Brown Clouds East Asia Regional Experiment 2005 (ABC-EAREX 2005) campaign. Previous studies used the exponentially decreasing pattern with altitude to represent the aerosol vertical profiles (e.g., Hayasaka et al., 2007; Li et al., 2010), and they reported that aerosol is present within $5 \mathrm{~km}$ in altitude for most of the cases (e.g., Sasano, 1996; Chiang et al., 2007). On the other hand, the aerosol vertical distribution does not always follow an exponential profile. For the longrange transported aerosol such as dust cases, the aerosol layer profile is quite different than the exponential profile and occasionally transported to well above the boundary layer (e.g., Reid et al., 2002; Johnson et al., 2008). The peak height of the aerosol extinction profile in long-range transport cases was reported to be located between 1 and $3 \mathrm{~km}$ during the Dust and Biomass-burning Experiment (DABEX) campaign (Johnson et al., 2008). From these previous studies, a standard aerosol vertical profile is difficult to determine. For algorithm development, previous studies assumed that the vertical distribution is a Gaussian function defined by peak height and half width as representative parameters (Torres et al., 1998, 2005). To supplement the simplicity of assumption for aerosol vertical distribution, the aerosol vertical distribution is assumed to be a quasi-Gaussian generalized distribution function (GDF), which is a Gaussian distribution with dependence on aerosol peak height, width, and layer top and bottom height. Details of the GDF can be found in Spurr and Christi (2014) and Yang et al. (2010). In this study, AEH ranges from 1 to $5 \mathrm{~km}$ with $1 \mathrm{~km}$ width as $1 \sigma$ for the RTM simulation.

\subsubsection{Atmospheric gases}

The vertical distribution of the $\mathrm{O}_{4}$ number density, which is used to calculate its SCD from the RTM, is assumed to be the square of the $\mathrm{O}_{2}$ number density in each layer (Hermans et al., 2003). Thus, the total number of the $\mathrm{O}_{4}$ column density from surface to the top of the atmosphere (TOA) is $1.38 \times 10^{43}$ molecule $\mathrm{cm}^{-5}$, where 93 and $73 \%$ of the total $\mathrm{O}_{4}$ is distributed below the altitude of 10 and $5 \mathrm{~km}$, respectively. In particular, signals by the changes of $\mathrm{O}_{4}$ are strong below $5 \mathrm{~km}$, where aerosol transport is observed frequently. The vertical distributions of other atmospheric components 


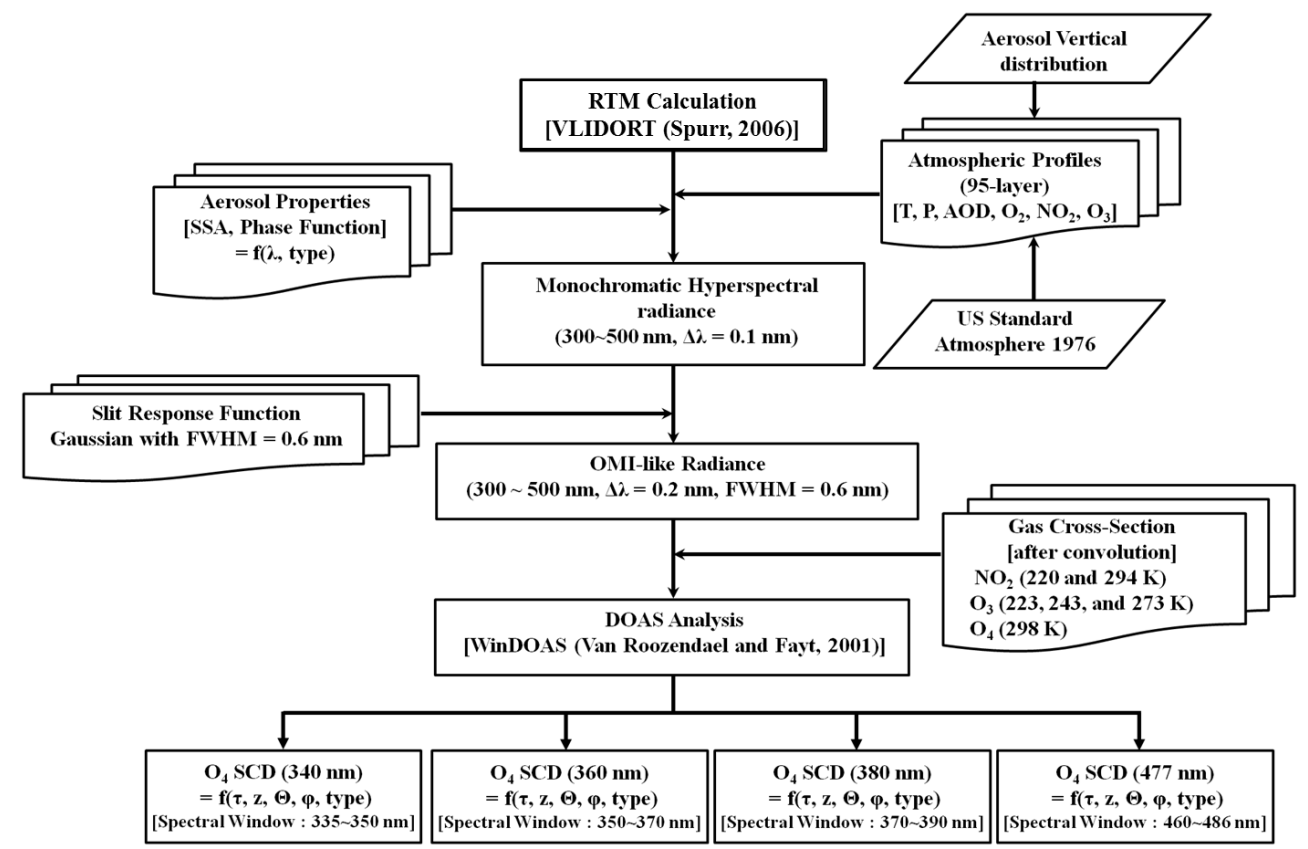

Figure 1. Flowchart of the simulated $\mathrm{O}_{4} \mathrm{SCD}$ estimation.

are taken from the US Standard Atmosphere 1976 (United States Committee on Extension to the Standard Atmosphere, 1976). The vertical distribution of trace gases and aerosol in the troposphere is interpolated in the $0.1 \mathrm{~km}$ resolution from the sea level to $5 \mathrm{~km}$.

\subsection{DOAS analysis for O4I estimation}

Table 1 summarizes the absorption cross sections of trace gases used as inputs for the radiance simulations and the DOAS spectral analysis. At wavelengths of $340,360,380$, and $477 \mathrm{~nm}$, the $\mathrm{O}_{4}$ absorption cross section from Hermans et al. (1999) is used in this study. $\mathrm{O}_{3}$ absorption cross sections at three different temperatures $(223,243$, and $273 \mathrm{~K})$ and $\mathrm{NO}_{2}$ absorption cross sections at two different temperatures $(220$ and $294 \mathrm{~K})$ are used to account for the amounts in the stratosphere and the troposphere. The radiance information obtained from the RTM simulation is analyzed to derive the $\mathrm{O}_{4}$ SCDs using WinDOAS software (van Roozendael and Fayt, 2001) before O4I estimation. To analyze the simulated radiances, the spectrum calculated without all atmospheric gases and aerosol is used as the Fraunhofer reference spectrum (FRS). The simulated spectra are fitted simultaneously with the absorption cross sections of all trace gases listed in Table 1 and FRS in the respective wavelength range of 335$350,350-370,370-390$, and $460-486 \mathrm{~nm}$, using a nonlinear least squares method (Platt and Stutz, 2008).

The O4I from OMI standard product of cloud (OMCLDO2) (e.g., Accarreta et al., 2004; Sneep et al., 2008) is used to adopt the AEH retrieval for case study. The OMCLDO2 basically used the cross section database from
Table 1. The database of cross sections used for DOAS fitting analysis.

\begin{tabular}{lll}
\hline Species & Temperature (K) & Reference \\
\hline $\mathrm{O}_{3}$ & 223,243, and 273 & Bogumil et al. (2001) \\
$\mathrm{NO}_{2}$ & 220 and 294 & Vandaele et al. (1998) \\
$\mathrm{O}_{4}$ & 298 & Hermans et al. (1999) \\
\hline
\end{tabular}

Newnham and Ballard (1998), considering the temperature dependence by interpolating it to a representative atmospheric temperature of $253 \mathrm{~K}$ (Accarreta et al., 2004). For this reason, there can be systematic difference between the O4I from OMCLDO2 and direct estimation from the observed radiance spectra in the present study. Figure 2 shows the $\mathrm{O}_{4} \mathrm{SCDs}$ from OMCLDO2 and those directly retrieved from the radiance spectrum over all observed OMI pixels on 31 March 2007 over East Asia. Similar to the DOAS analysis using the simulated spectra for a look-up table (LUT) calculation, OMI-observed radiance spectra are fitted with the Ring spectrum and the FRS in addition to the absorption cross sections in Table 1 within the same wavelength window. Before the spectral fitting, the $\mathrm{NO}_{2}$ and $\mathrm{O}_{3}$ cross sections are $I_{0}$ corrected, and the Ring spectrum (Fish and Jones, 1995), accounting for the effects of the rotational Raman scattering due to air molecules, is calculated using the WinDOAS software (van Roozendael and Fayt, 2001). After the fitting, the noise level of residual spectra is estimated to be on the order of $10^{-3}$ for the radiance spectrum at $477 \mathrm{~nm}$ from OMI measurements. The $\mathrm{O}_{4} \mathrm{SCDs}$ with the fitting error 


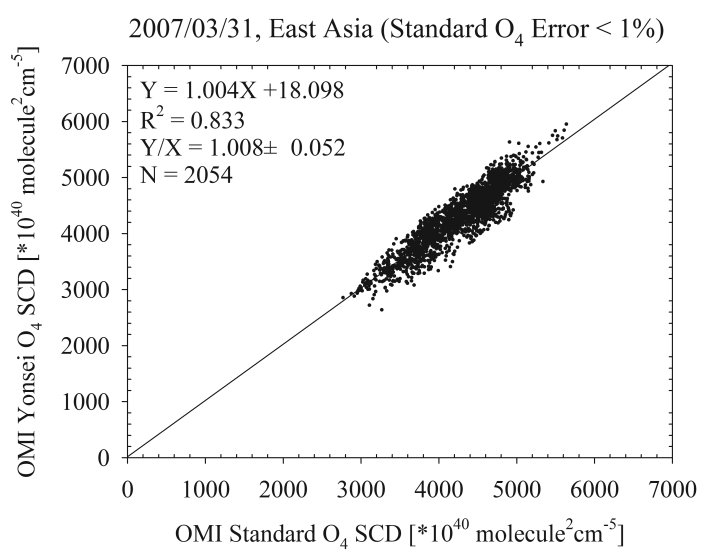

Figure 2. Comparison of $\mathrm{O}_{4} \mathrm{SCD}$ directly retrieved from OMI radiance with the OMI standard product on 31 March 2007.

less than $1 \%$ are used for the comparison. From this figure, a systematic difference between the two different fitting results is less than $1 \%$, although the cross section databases for fitting are different. From this result, the effect of cross section database difference is negligible when the same observation data were used. Furthermore, the DOAS analysis for LUT calculation can be used to compare the $\mathrm{O}_{4} \mathrm{SCD}$ from OMCLDO2.

Figure 3 shows the comparison of the $\mathrm{O}_{4} \mathrm{SCD}$ at $477 \mathrm{~nm}$ from LUT with the dimension as in Table 2 against OMCLDO2 for aerosol and cloud free pixels in year 2005. The LUT of $\mathrm{O}_{4} \mathrm{SCD}$ is estimated by the DOAS analysis using simulated radiance from VLIDORT with various geometries as shown in Table 2. The clear-sky region is selected for the Pacific Ocean with cloud fraction less than 0.02 from OMI observation. The surface albedo is assumed to be 0.05 , which is similar to the minimum Lambertian equivalent reflectance (LER) over clear ocean surface (e.g., Kleipool et al., 2008). Because the standard product of the $\mathrm{O}_{4} \mathrm{SCD}$ is only estimated at the $477 \mathrm{~nm}$ band, the results can be compared only at this band. To minimize the DOAS fitting error, the observed data from OMI are selected by the fitting precision less than $2 \%$ and the quality flags for spectral fitting are also considered. As shown in Fig. 3a, the coefficient of determination $\left(R^{2}\right)$ is 0.864 with a slope of 1.050 , and the LUT exhibits a ratio of $0.86 \pm 0.05$ to the values obtained from OMI standard values. Despite the statistically significant $R^{2}$ and slope values between the two values, there is a negative bias of about $14 \%$.

The bias between the values retrieved from LUT and estimated from the standard product can be attributed to the differences in the $\mathrm{O}_{4}$ cross section data and the lack of their temperature and pressure dependence as noted from the previous works by Wagner et al. (2009); Clémer et al. (2010), and Irie et al. (2015). For this reason, ground-based measurements adopted the correction factors in the cross section database. However, the bias effect for the cross section differ-
Table 2. Dimensions of LUT for the clear-sky comparison.

\begin{tabular}{lll}
\hline Variable name & No. of entries & Entries \\
\hline SZA & 7 & $0,10,20,30,40,50,60^{\circ}$ \\
VZA & 7 & $0,10,20,30,40,50,60^{\circ}$ \\
RAA & 10 & $0,20,40,60,80,100$, \\
& & $120,140,160,180^{\circ}$ \\
\hline
\end{tabular}

SZA is the solar zenith angle; VZA is the viewing zenith angle; RAA is the relative azimuth angle.

(a) Year 2005, Fit error $<2 \%$, Pacific Ocean, Cloud Fraction $<0.02$

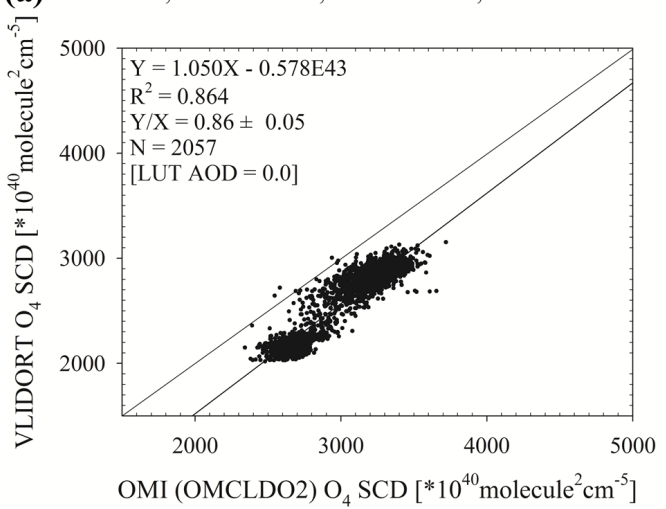

(b) Year 2005, Fit error $<2 \%$, Pacific Ocean, Cloud Fraction $<0.02$

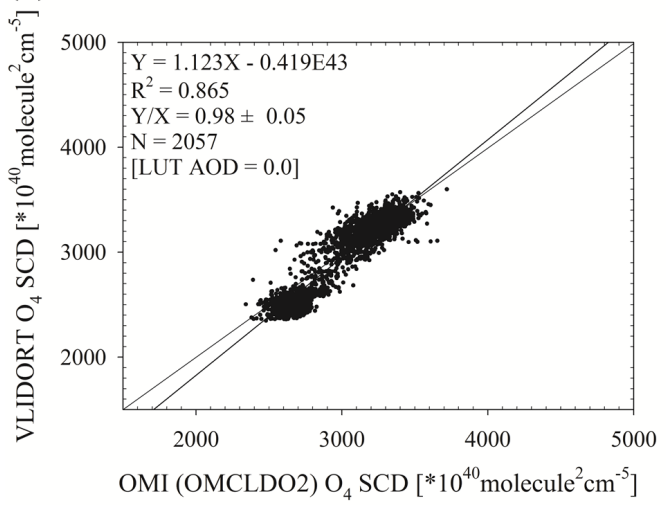

Figure 3. Comparison of the $\mathrm{O}_{4} \mathrm{SCD}$ at $477 \mathrm{~nm}$ between the OMI standard product and the calculated value from LUT (a) before and (b) after correction of LER.

ence is limited as shown in Fig. 2, and the correction factor for the cross section database in the previous studies cannot be applied to the space-borne measurements. In Kleipool et al. (2008) the minimum LER is defined to be the $1 \%$ cumulative probability threshold, and frequent LER values are typically higher than minimum LER over clear ocean, although cloud screening was perfectly executed before LER calculation. To account for the difference between simulated and observed SCD, the LUT was recalculated by changing the condition to the surface albedo of 0.10 . Although the assumed surface albedo is higher than minimum LER from Kleipool et al. (2008), the surface albedo of 0.10 is a realistic value 
for ocean surface albedo at midlatitudes (e.g., Payne, 1972). The corrected result is shown in Fig. 3b, with the $R^{2}$ of 0.865 similar to that before the correction, while the negative bias is removed to $0.98 \pm 0.05$ and the regression line slope is 1.123 . Although the comparison result is not perfect, the calculation by the VLIDORT simulates the satellite observation and can be used for sensitivity tests and case studies to retrieve aerosol height.

\section{Sensitivity test}

\subsection{Sensitivity of the O4Is to the AEH}

The sensitivity of the O4I to the AEH is investigated for its absorption bands at 340,360, 380, and $477 \mathrm{~nm}$. Figure 4 shows the O4I as a function of the AEH and the three different aerosol types of MITR, WASO, and COPO at 360, 380, and $477 \mathrm{~nm}$, respectively. The vertical error bar represents the fitting error estimated by the residual spectra from the DOAS fitting (e.g., Stutz and Platt, 1996). For the calculation shown in the figures, the following geometries are assumed: solar zenith angle (SZA) of $30^{\circ}$, viewing zenith angle (VZA) of $30^{\circ}$, and relative azimuth angle (RAA) of $100^{\circ}$. Note that an insignificant SCD value was estimated at $340 \mathrm{~nm}$ due to the large spectra fitting error. In these three figures, the O4Is show the AEHs ranging from 1.0 to $5.0 \mathrm{~km}$ for the AODs of 1.0 and 2.5 at $500 \mathrm{~nm}$, which could be due to the existence of thick aerosol layers. For the sensitivity result, the decrease rate of the $\mathrm{O} 4 \mathrm{I}$ value in the $1 \mathrm{~km}$ interval of $\mathrm{AEH}\left(-\mathrm{dO}_{4} / \mathrm{d} Z\right)$ is defined as equivalent $\mathrm{O} 4 \mathrm{I}$ difference converted from the O4I difference between the neighboring AEHs in the same AOD condition.

The O4Is are estimated at 360 and $380 \mathrm{~nm}$ bands as shown in Fig. 4a-f. The O4I is significantly decreased with increasing AEH at 360 and $380 \mathrm{~nm}$ for all aerosol types. However, negative O4Is are occasionally estimated at $360 \mathrm{~nm}$. Furthermore, the fitting errors are too large to estimate the AEH, which range from 160 to 410 at $360 \mathrm{~nm}$ and from 350 to 1060 at $380 \mathrm{~nm}$. From large fitting errors with small O4I, the fitting results are insignificant at these two absorption bands.

Nonetheless, the sensitivity of the O4I at $477 \mathrm{~nm}$ is a significant variable to estimate $\mathrm{AEH}$. The mean value of $-\mathrm{dO}_{4} / \mathrm{dZ}$ is estimated to be 87,290 , and 190 for the MITR, WASO, and COPO respectively when the AOD is 1.0 . The mean value of $-\mathrm{dO}_{4} / \mathrm{dZ}$ on the AOD of 2.5 is estimated to be 94, 362, and 213 for the MITR, WASO, and COPO, respectively. The calculated $-\mathrm{dO}_{4} / \mathrm{dZ}$ is significantly larger than the mean O4I fitting error of 58, which implies that the O4I at $477 \mathrm{~nm}$ is useful in estimating the AEH. The small fitting errors at $477 \mathrm{~nm}$ are due to the larger $\mathrm{O}_{4}$ absorption and less interference by other trace gases in this spectral window.

Figure 5 shows $-\mathrm{dO}_{4} / \mathrm{dZ}$ as changing viewing geometries. As geometrical path length for viewing geometry is enlarged, $-\mathrm{dO}_{4} / \mathrm{dZ}$ also increases because the path length
Table 3. Dimensions of simulation cases for the error analysis of the AEH retrieval.

\begin{tabular}{lll}
\hline Variable name & No. of entries & Entries \\
\hline SZA & 7 & $0,10,20,30,40,50,60^{\circ}$ \\
VZA & 7 & $0,10,20,30,40,50,60^{\circ}$ \\
RAA & 10 & $0,20,40,60,80,100,120$, \\
& & $140,160,180^{\circ}$ \\
AOD & 5 & $0.4,1.0,1.6,2.5,3.0$ \\
AEH & 8 & $1.0,1.2,1.6,2.0,2.4,3.0,4.0,5.0 \mathrm{~km}$ \\
Aerosol model & 3 & MITR, WASO, COPO \\
Surface albedo & 1 & 0.10 \\
\hline
\end{tabular}

AOD is the aerosol optical depth; AEH is the aerosol effective height.

through the aerosol layer is also increased. The mean value of $-\mathrm{dO}_{4} / \mathrm{dZ}$ including all cases of $\mathrm{AEH}$ is estimated to be 90 to 326 at SZA of $30.0^{\circ}$ and VZA of $30.0^{\circ}$, while it is estimated to be 265 to 485 at $\mathrm{SZA}$ of $60.0^{\circ}$ and VZA of $60.0^{\circ}$. Although the aerosol scattering angle is changed by SZA and VZA, the $\mathrm{O} 4 \mathrm{I}$ sensitivity to AEH is generally increased with increasing optical path length to the viewing geometries. From this result, the accuracy for the AEH retrieval is potentially better for large zenith angle cases than for low zenith angle cases.

\subsection{Error analysis}

Errors are also estimated in terms of key variables in the estimation of the O4I at $477 \mathrm{~nm}$, with the variables and their dimensions as summarized in Table 3. For the error analysis of AEH retrieval, characteristics for all of extinction properties are essential to consider. In this study, errors are analyzed in terms of AOD, aerosol vertical distribution, particle size, and SSA for aerosol amount and properties. Surface albedo variation is also considered to represent surface condition. To estimate the error amount, the AEH error is converted from the half of O4I difference between adding and deducting perturbation of variables as shown in Eq. (1).

$\varepsilon(Z)=\left|\frac{\mathrm{O} 4 \mathrm{I}(x+\delta x, Z)-\mathrm{O} 4 \mathrm{I}(x-\delta x, Z)}{2.0 \times \mathrm{dO}_{4} / \mathrm{d} Z(x, Z)}\right|$,

where $\varepsilon(Z)$ is the AEH error amount due to variable of error source, $x$, in AEH of $Z$, and $\delta x$ is perturbation of AEH retrieval error source. The $\varepsilon(Z)$ value also depends on viewing geometries. Therefore $\varepsilon(Z)$ is represented for specific geometries together with averaging over all geometries.

\subsubsection{AOD}

The O4I at $477 \mathrm{~nm}$ has sensitivity not only for AEH but also for AOD as shown in Fig. 4g-i. Because the radiance extinction by aerosol changes depending on AOD, the optical path length of TOA radiance is also affected by AOD. For different AODs $\left(\tau_{a}\right)$, the O4I at AEHs of 1.0 and $3.0 \mathrm{~km}$ is shown in Fig. 6 for the same geometry assumed in Fig. 4. From OMI standard products, the expected error of the AOD over ocean is the larger of 0.1 or $30 \%$ for absorbing aerosol and 


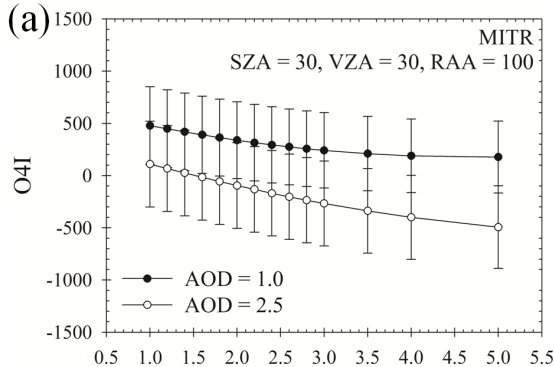

$\mathrm{AEH}[\mathrm{km}]$
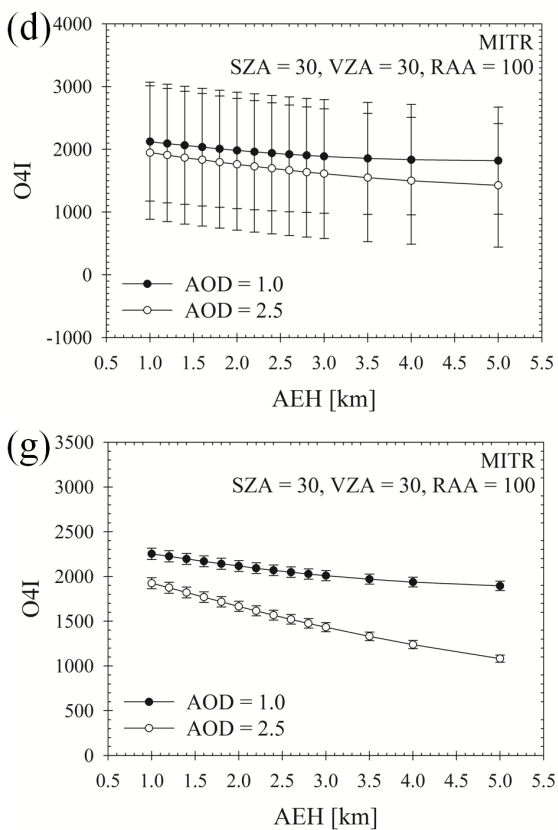

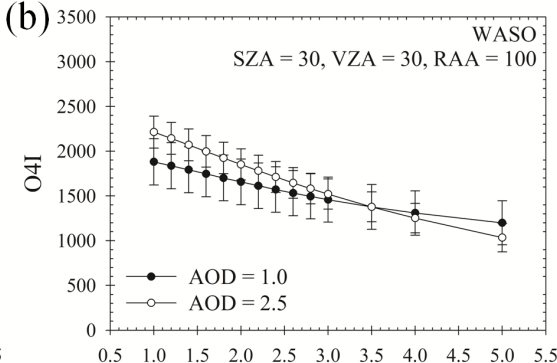

AEH $[\mathrm{km}]$
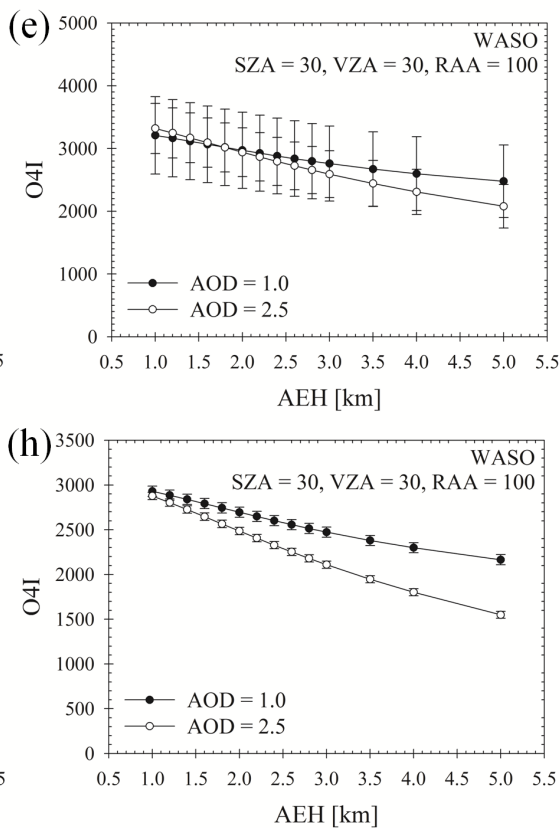

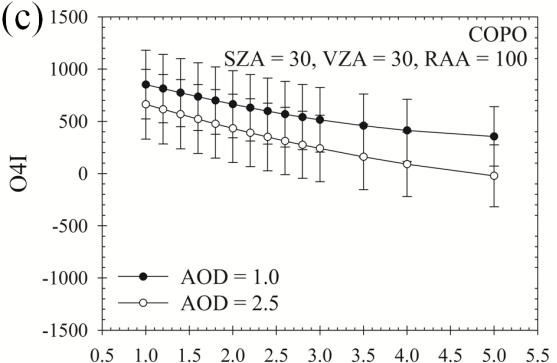

AEH $[\mathrm{km}]$
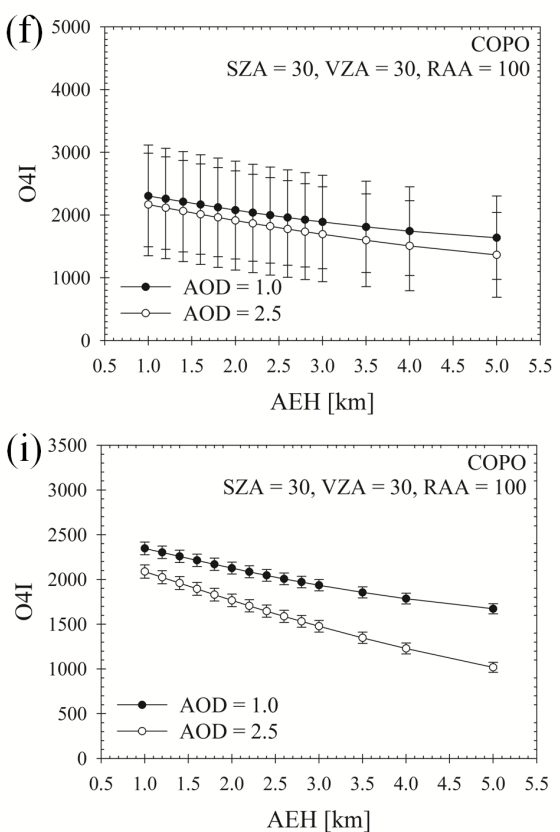

Figure 4. The O4I at $360 \mathrm{~nm}$ band for (a) MITR, (b) WASO, and (c) COPO; (d) at $380 \mathrm{~nm}$ band for MITR, (e) WASO, and (f) COPO; and (g) at $477 \mathrm{~nm}$ band for MITR, (h) WASO, and (i) COPO as a function of AEH.

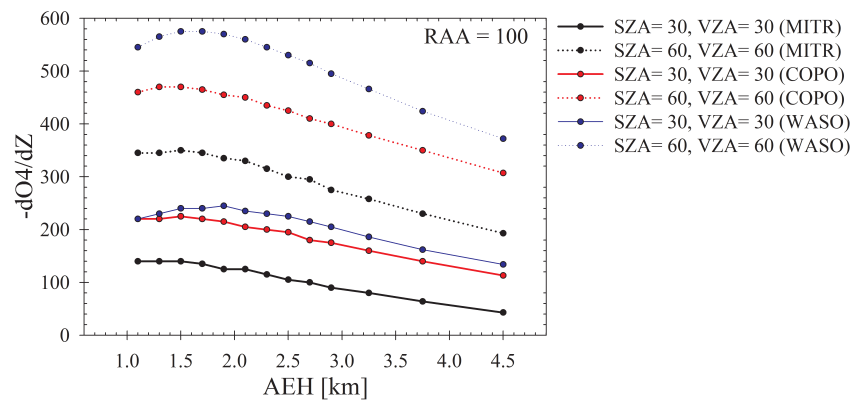

Figure 5. The AEH sensitivity to $\mathrm{O} 4 \mathrm{I}\left(-\mathrm{dO}_{4} / \mathrm{d} Z\right)$ with changing observation geometries at $477 \mathrm{~nm}$.

the larger of 0.1 or $20 \%$ for non-absorbing aerosol (Torres et al., 1998, 2002). For this reason, the uncertainty of AOD is assumed to be 0.1 in this study, although uncertainty of AOD would be larger than the assumed value for large AOD. The decreasing rate of the $\mathrm{O} 4 \mathrm{I}\left(-\mathrm{dO}_{4} / \mathrm{d} \tau_{a}\right)$, which defines O4I reduction with an AOD increase by 0.1 , is found to be larger for the $\mathrm{AEH}$ at $3.0 \mathrm{~km}$ than for that at $1.0 \mathrm{~km}$. Among the three aerosol types, the $-\mathrm{dO}_{4} / \mathrm{d} \tau_{a}$ is found to be the least for the WASO, which has stronger scattering characteristics than other two aerosol types. In addition, the sensitivity for WASO showed negative $-\mathrm{dO}_{4} / \mathrm{d} \tau_{a}$ for small AOD at low $\mathrm{AEH}$, which has a small shielding effect with a large enhancement effect due to the large SSA of WASO. The mean $-\mathrm{dO}_{4} / \mathrm{d} \tau_{a}$ values are estimated to be $1.2,0.9$, and $-0.1 \%$ for the AEH of $1.0 \mathrm{~km}$ as the AOD changes by 0.1 for the MITR, COPO, and WASO, respectively, whereas they are estimated to be $2.3,2.1$, and $1.0 \%$ for the AEH of $3.0 \mathrm{~km}$ with respect to the same AOD changes for the three different types, respectively.

Figure 7 shows the expected error in AEH due to retrieval uncertainty of AOD from observations. Because $\mathrm{O}_{4}$ concentration exponentially decreases as the atmospheric altitude increases, the sensitivity to AEH becomes weak at high AEHs. In addition, aerosol signal is relatively weak for low AOD. From these reasons, the AEH retrieval error due to AOD uncertainty is maximized for the high AEH with low 

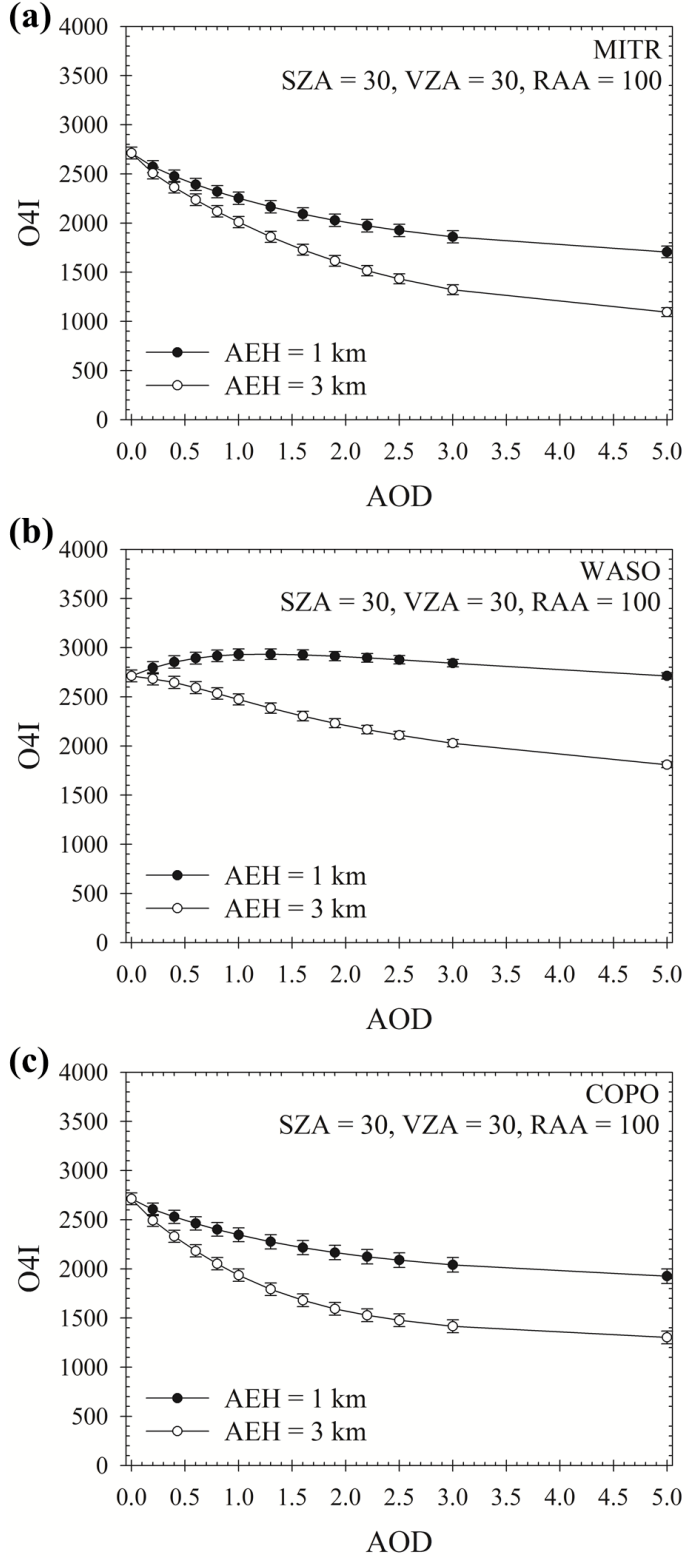

Figure 6. The O4I of (a) MITR, (b) WASO, and (c) COPO types as a function of AOD.

AOD cases for all aerosol types. The maximum retrieval error is 2.0, 0.7, and $4.4 \mathrm{~km}$ for COPO, WASO, and MITR for the case at AEH of $4.0 \mathrm{~km}$ and AOD of 0.4, which is the least sensitive case for AEH. For an AOD of 0.4, however, the retrieval error due to AOD uncertainty is $0.3,0.2$, and $0.4 \mathrm{~km}$ for COPO, WASO, and MITR for the case at AEH of $1.0 \mathrm{~km}$. Except for AEH lower than $4 \mathrm{~km}$ and an AOD larger than 0.4, the retrieval error of $\mathrm{AEH}$ is less than $1.0 \mathrm{~km}$ for all viewing geometries and all aerosol types.

Furthermore, the AEH error for AOD uncertainty is also dependent on viewing geometries. From previous studies, the error for cloud height information depends on the observa- (a)

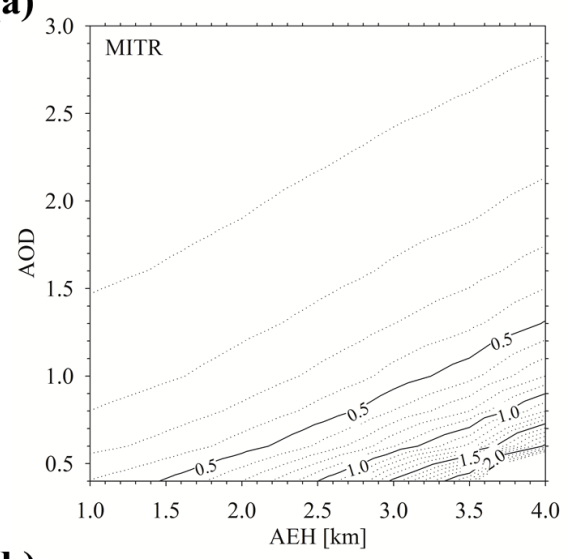

(b)

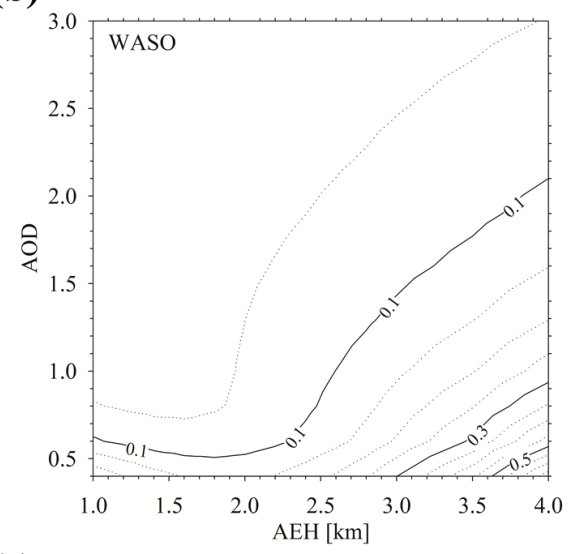

(c)

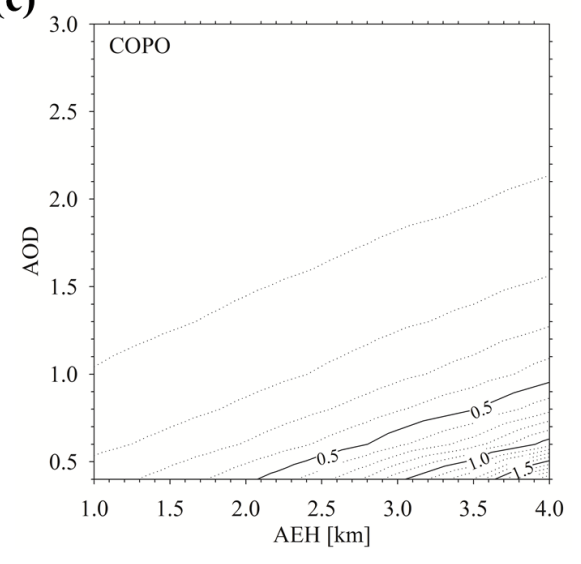

Figure 7. AEH error of (a) MITR, (b) WASO, and (c) COPO for the AOD difference of 0.1 as a function of reference AEH and AOD.

tion geometries due to changing average optical path length (Accarreta et al., 2004; Chimot et al., 2015). Moreover, the retrieval error sensitivity for observation geometries is also found in aerosol height estimation by the $\mathrm{O}_{2} \mathrm{~A}$ band (Sanders et al., 2015). Similar to these previous studies, the AEH error becomes larger for short light paths and smaller for long paths. Figure 8 shows the viewing geometry dependence of AEH error for an AOD of 1.0. With the increase in effective optical path length, the radiance signal from aerosol is also 
(a)

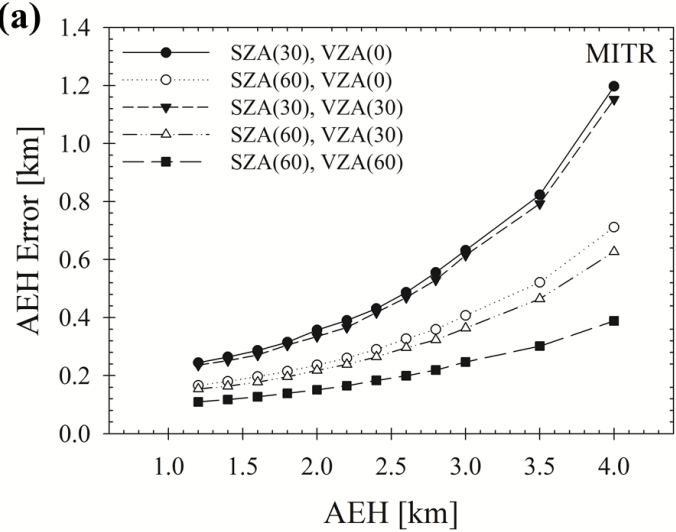

(b)
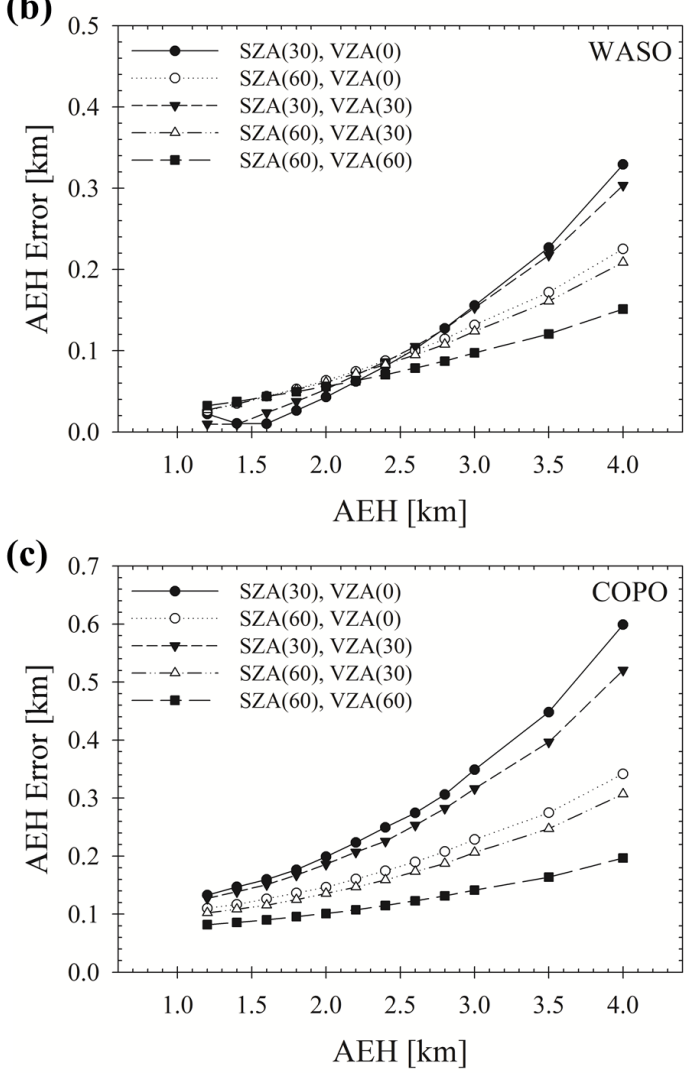

Figure 8. AEH error of (a) MITR, (b) WASO, and (c) COPO for the AOD difference of 0.1 as changing viewing geometries.

enhanced. In general, the AEH error decreases with increasing viewing geometries. For WASO case, however, the AEH error is smaller for the short path length than the long path length in the low AEH case. For the thin aerosol layer situation, the radiance is enhanced by scattering aerosols, which results in increasing optical path length. In the small SZA and VZA, aerosol layer effectively causes enhancement effect. With increasing SZA and VZA, however, the shielding effect due to the aerosol layer enhances because radiance has to pass through the long path through the aerosol layer. For this reason, the smallest error case is the inflection point (a)

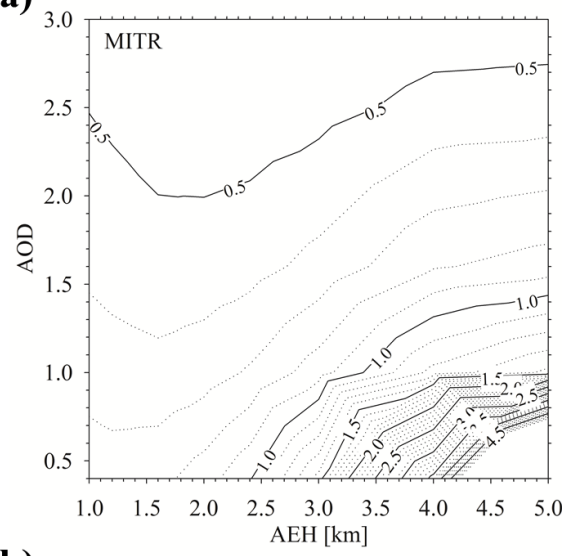

(b)

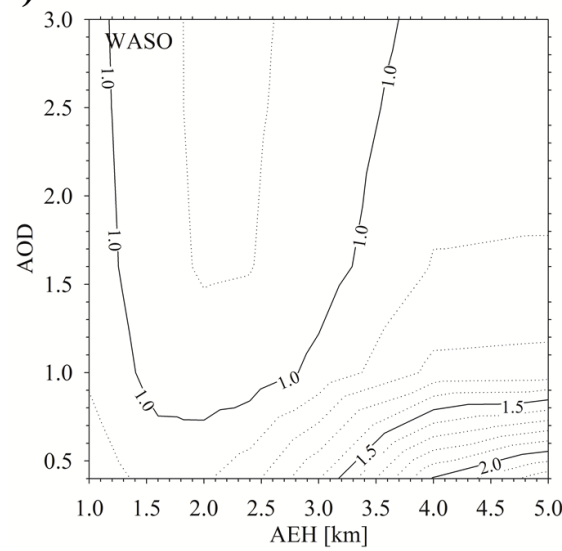

(c)

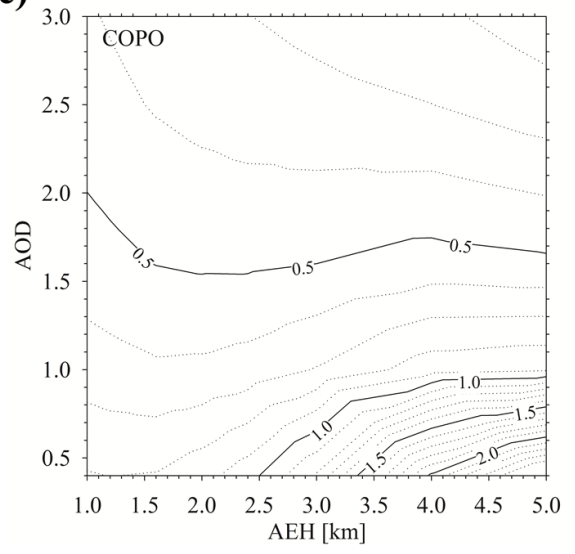

Figure 9. Same as Fig. 7 except for SSA difference of $10 \%$.

of AOD sensitivity, which corresponds to a turnaround point with a larger shielding effect than enhancement effect.

\subsubsection{SSA}

Torres et al. (1998) showed that the result of the SSA from OMI can be overestimated due to the cloud contamination, although the aerosol retrieval algorithm considers the existence of clouds in sub-pixel. Furthermore, the SSA varies 
(a)

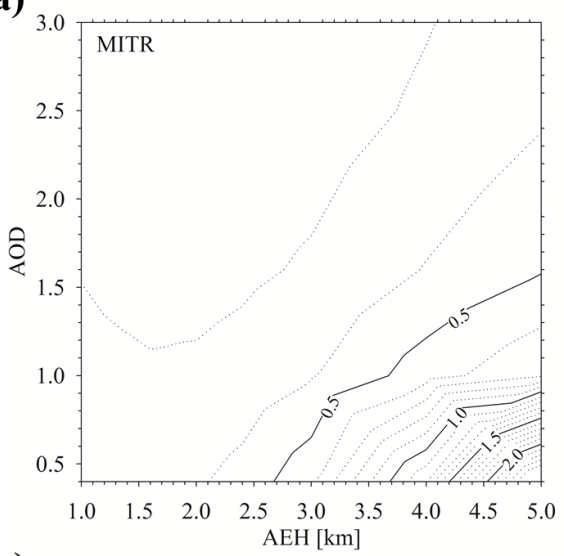

(b)

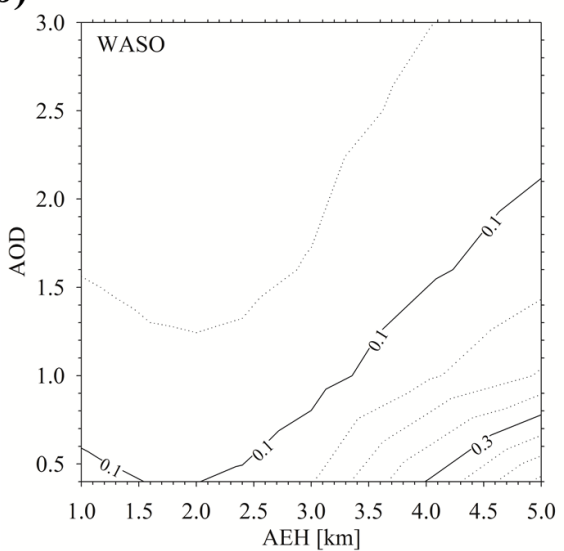

(c)

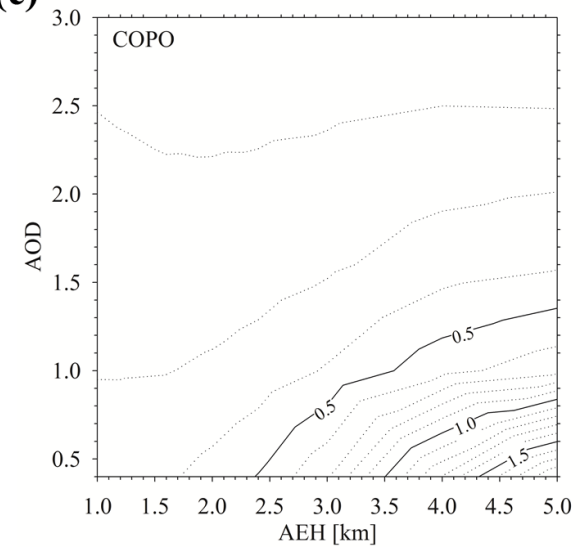

Figure 10. Same as Fig. 7 except for particle size difference of $20 \%$.

widely for different aerosol types. Therefore, the sensitivity of O4I to the SSA variation is estimated for the same geometries used in the previous tests. To estimate O4I sensitivity to the SSA variation, the imaginary part of the refractive index value corresponding to $10 \%$ variability for SSA is changed after fixing the real part of the refractive index. The mean O4I changes by 106, 282, and 205 for MITR, WASO, and COPO, respectively, with respect to its SSA deviation by $10 \%$. To (a)

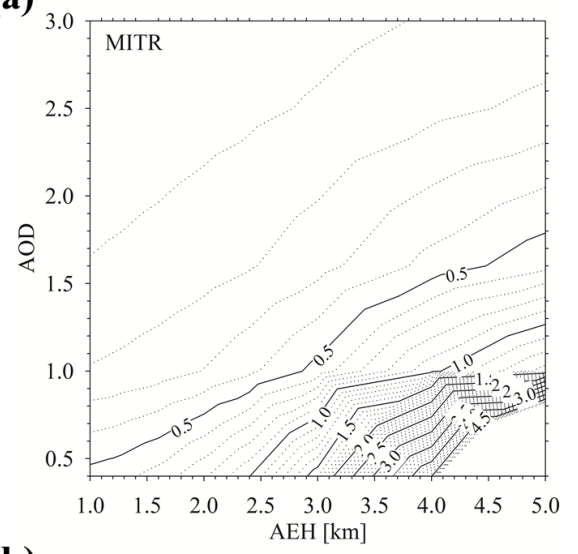

(b)

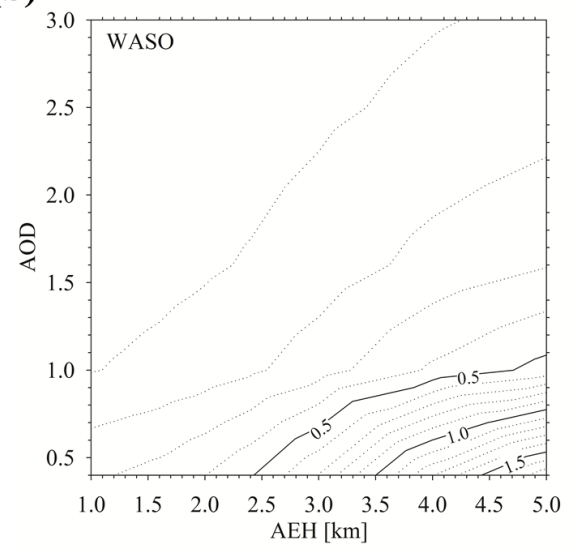

(c)

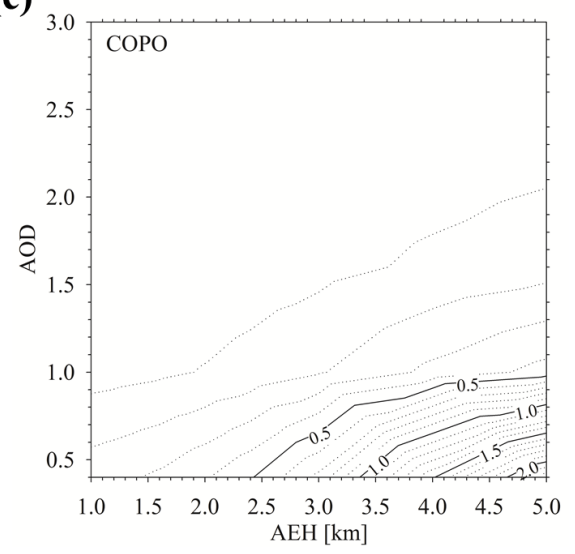

Figure 11. Same as Fig. 7 except for surface albedo difference of 0.02 .

compare the difference for WASO and COPO, it is proportional to the absolute values of the SSA for all simulated cases. In addition, the difference for MITR is smaller than that for COPO, because less fraction of back scattering in coarse-mode particles makes it less sensitive to O4I change.

Figure 9 shows the AEH error due to the SSA variation by $10 \%$. Because of the low sensitivity characteristics of AEH as shown in Sect. 3.1, large errors are shown for high AEH and low AOD cases. However, the AEH errors are less 


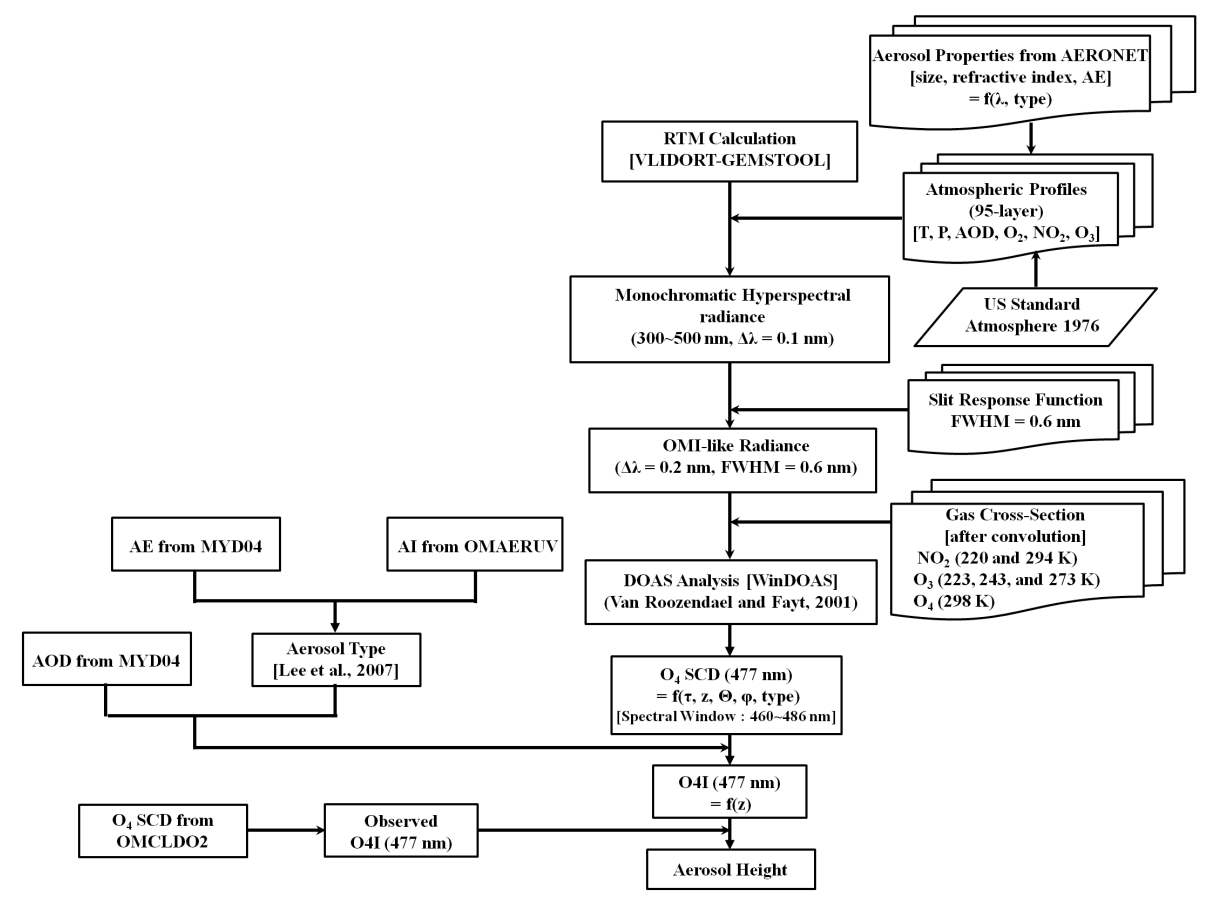

Figure 12. Flowchart of the retrieval algorithm for AEH from OMI observation.

than $1 \mathrm{~km}$ for COPO aerosol type. For an AOD of 1.0, the AEH error due to SSA variation is estimated to be 610 to $900 \mathrm{~m}$ for the COPO type. Furthermore, the error is calculated to range from 270 to $1220 \mathrm{~m}$ and from 930 to $1400 \mathrm{~m}$ for COPO and WASO types, respectively, if AEH is $3 \mathrm{~km}$, the frequently assumed reference altitude in the aerosol retrieval algorithm (e.g., Torres et al., 1998). For MITR, a dust-like type of aerosol, the AEH error, which ranges from 410 to $1430 \mathrm{~m}$ for an AOD of 1.0, is generally the largest compared to AEH errors of other aerosol types. In general, uncertainty of aerosol optical properties is large for the thin aerosol layer case and thus the uncertainty of the AEH is as well.

\subsubsection{Particle size}

Aerosol particle size has noticeable effects on the phase function and thus also the directional scattered intensity. However, most aerosol retrieval algorithms assume aerosol particle size depending on its type as an input parameter to RTM calculation. Although aerosol type is categorized, physical properties of aerosol can be changed according to the source type and transport characteristics. In the OMI aerosol algorithm, size distribution is one of the error sources for the AOD (Torres et al., 2002).

Figure 10 shows the AEH error due to particle size change. For error estimation, the mode radius difference for number size distribution is assumed to be $\pm 20 \%$, which corresponds to a range that is 4 times larger than that from the error budget study for the OMI standard product (Torres et al., 2002). Overall, the O4I difference is within the order of 100.
The coarse-mode aerosol, MITR in this study, results in the largest O4I difference for all cases; thus the largest AEH error for MITR is estimated to range from 0.2 to $2.7 \mathrm{~km}$. The error ranges from 0.03 to 0.5 and from 0.2 to $1.9 \mathrm{~km}$ for WASO and COPO, respectively. The largest AEH errors for the three aerosol types are estimated for the case with an AOD of 0.4 and $\mathrm{AEH}$ at $5.0 \mathrm{~km}$.

\subsubsection{Surface albedo}

As the surface albedo affects the $-\mathrm{dO}_{4} / \mathrm{d} Z$, the sensitivity of the O4I is also tested with respect to the surface albedo difference of 0.02 . The difference of climatological surface albedo between that obtained from the total ozone monitoring spectrometer (TOMS) and the global ozone monitoring experiment (GOME) was known to be up to 0.02 (Koelemeijer et al., 2003). Table 4 shows the sensitivity of the O4I with respect to the change in the surface albedo. The absolute difference of $\mathrm{O} 4 \mathrm{I}$ due to surface albedo variation is below 85 . Because aerosol layer attenuates the reflected radiance from surface, the absolute difference of O4I value decreases as aerosol amount increases. Furthermore, it is found that the difference of O4I due to surface albedo change is larger for non-absorbing aerosol than absorbing aerosol, because absorbing aerosol attenuates the reflected radiance more than non-absorbing aerosol. In terms of AEH change, the O4I difference increases as AEH increases. For the low AEH case, optical path length of reflected radiance from the surface to the aerosol layer is relatively short compared to the high $\mathrm{AEH}$ case. For this reason, the O4I sensitivity for surface 
Table 4. Absolute difference of O4I for changing surface albedo by 0.02 .

\begin{tabular}{llll}
\hline & MITR & WASO & COPO \\
\hline Maximum & 81 & 85 & 76 \\
Case [AOD, AEH $(\mathrm{km})]$ & {$[0.4,5.0]$} & {$[0.4,5.0]$} & {$[0.4,5.0]$} \\
Minimum & 8 & 11 & 1 \\
Case [AOD, AEH $(\mathrm{km})]$ & {$[3.0,1.0]$} & {$[3.0,1.0]$} & {$[3.0,1.0]$} \\
Mean \pm standard deviation & $38 \pm 22$ & $37 \pm 20$ & $20 \pm 21$ \\
\hline
\end{tabular}

albedo is reduced by the high concentration of aerosol near the surface for the low AEH case.

Figure 11 shows the expected retrieval error of AEH due to surface albedo difference as changing AEH with respect to AOD and its types. As mentioned in the previous section, the $-\mathrm{dO}_{4} / \mathrm{dZ}$ is small in high $\mathrm{AEH}$ and low AOD cases. Furthermore, the albedo sensitivity increases as AEH increases and AOD decreases. As a result, the AEH error is frequently larger than $1 \mathrm{~km}$ for high AEH with small AOD, especially when the AOD is less than 0.4. Because reflected radiance from surface is dominant for the thin aerosol case, the AEH error in high AEH with low AOD shows the largest value as compared to previous error analysis. However, the AEH error sharply decreases as AOD increases and AEH decreases, when aerosol signal becomes dominant. Especially for MITR, four simulation cases, when $\mathrm{AOD}=0.4$ with $\mathrm{AEH}$ $>3.0 \mathrm{~km}$ and $\mathrm{AOD}=1.0$ with $\mathrm{AEH}=5.0 \mathrm{~km}$, show the $\mathrm{AEH}$ error larger than $1 \mathrm{~km}$. Because $-\mathrm{dO}_{4} / \mathrm{dZ}$ is too small in these cases, AEH retrievals in the four simulation cases show limitation as a reliable result. For COPO and WASO, however, all the cases in AEH $<3.0 \mathrm{~km}$, which directly influence surface concentration, show errors lower than $750 \mathrm{~m}$, even for the assumed AOD of 0.4. In addition, errors less than $500 \mathrm{~m}$ are found for AOD $>1.0$ with AEH $<3.0 \mathrm{~km}$.

\subsubsection{Vertical distribution}

Aerosol vertical distribution varies largely by distance from the source, atmospheric dynamics during aerosol transport, and sink mechanism in reality. To estimate the AEH error due to variation of aerosol vertical distribution, the half width of GDF distribution was doubled for comparison. Although it is not possible here to consider all kinds of aerosol vertical distributions due to the large variability of aerosol in profile, aerosol vertical distribution by changing the half width of GDF distribution can reflect large-scale changes in its vertical profile.

Table 5 shows the mean AEH errors between the two vertical profiles of aerosol as AOD changes. As the aerosol vertical profile is changed with an increase in its widths, the difference of O4I ranges from 100 to 430 . Because the aerosol vertical profile simultaneously affects aerosol concentration and layer thickness, the O4I difference shows a large value as the vertical distribution changes. For this rea- son, the AEH error is larger than $2.5 \mathrm{~km}$ for all aerosol types with an AOD of 0.4. The estimated errors caused solely by the change between the two aerosol vertical profiles, range $1477 \pm 602,722 \pm 190$, and $671 \pm 265 \mathrm{~m}$ for the MITR, COPO, and WASO, respectively, for an AOD greater than 1.0.

\subsection{Error budget}

Table 6 shows the summary of the total error budget for the AEH estimation with a list of the major error sources and their values, assuming errors in each variable in OMI standard products. To convert the O4I difference to the AEH error, the difference of $\mathrm{O} 4 \mathrm{I}$ due to the respective error source is divided by that from the change of the AEH in each bin of the AOD and AEH as shown in Sect. 3.2, with the simulation cases over 58800 runs listed in Table 3 to calculate mean and standard deviation of errors. Because of weak signal sensitivity to AEH for AOD of 0.4 and AEH at $5.0 \mathrm{~km}$ as shown in the previous section, this simulation case is omitted in calculating statistical values for error budget. In summary, the total number of aerosol simulations for the combination of AOD and AEH includes 39 cases.

The mean errors from $10 \%$ variation in the SSA for all of the variable conditions in Table 3 correspond to 726, 576, and $1047 \mathrm{~m}$ for the MITR, COPO, and WASO, respectively. For the total error budget calculations, however, SSA change by $5 \%$ was used according to Torres et al. (2007), which reported the variation of the SSA less than 0.03 for the given aerosol type. The error from the vertical distribution is estimated to be 720,1480 , and $690 \mathrm{~m}$ for the COPO, MITR, and WASO, respectively.

The errors from SSA and aerosol profile shape are the two important error sources in estimating the AEH, followed by the errors related to AOD and surface albedo. From these results, the errors of the AEH due to the error from OMI AOD of 0.1 and the surface albedo of 0.02 are less than $300 \mathrm{~m}$ for WASO and COPO, and about $400 \mathrm{~m}$ for MITR. However, the AEH error from surface albedo is important for cases with low AOD at high AEH, which is the surface reflectance dominant case.

The mean errors from $20 \%$ variation in the aerosol particle size are 726, 576, and $1047 \mathrm{~m}$ for the MITR, COPO, and WASO, respectively. Torres et al. (2002) assumed the variation of size distribution to be $5 \%$. Thus, for the total error budget calculations assuming $5 \%$ change in the particle size, the AEH errors are less than $100 \mathrm{~m}$. In addition, the errors in the O4I, and thereby the AEH, are associated with the variations in the column amounts and the differences in the absorption cross section of each fitted trace gas for the spectral analysis. The variations in the column amounts of trace gases and the differences in the absorption cross section values do not affect the calculation of the O4I significantly. However, the $\mathrm{O}_{4}$ vertical column density is changed by the variation in atmospheric pressure. In East Asia, the surface pressure over 
Table 5. The error for AEH due to the change in aerosol vertical distribution.

\begin{tabular}{llll}
\hline $\begin{array}{l}\text { Reference shape } \\
(\text { Width }=1 \mathrm{~km})\end{array}$ & $\begin{array}{l}\text { MITR } \\
(\text { Width }=2 \mathrm{~km})\end{array}$ & $\begin{array}{l}\text { WASO } \\
(\text { Width }=2 \mathrm{~km})\end{array}$ & $\begin{array}{l}\text { COPO } \\
(\text { Width }=2 \mathrm{~km})\end{array}$ \\
\hline Error for AEH $(\mathrm{m})$ & $1477 \pm 602$ & $671 \pm 265$ & $722 \pm 190$ \\
\hline
\end{tabular}

Table 6. Summary of error sources and total error budget for the AEH retrieval.

\begin{tabular}{|c|c|c|c|}
\hline Error source & MITR & WASO & $\mathrm{COPO}$ \\
\hline $\mathrm{AOD}(\Delta \mathrm{AOD}=0.2)$ & $387 \pm 740 \mathrm{~m}$ & $105 \pm 131 \mathrm{~m}$ & $218 \pm 358 \mathrm{~m}$ \\
\hline SSA (10\% change) & $726 \pm 537 \mathrm{~m}$ & $1047 \pm 194 \mathrm{~m}^{1}$ & $576 \pm 332 \mathrm{~m}$ \\
\hline Surface albedo $(\Delta \alpha=0.02)$ & $438 \pm 762 \mathrm{~m}$ & $199 \pm 241 \mathrm{~m}$ & $154 \pm 274 \mathrm{~m}$ \\
\hline Particle size ( $20 \%$ change) & $352 \pm 174 \mathrm{~m}$ & $72 \pm 56 \mathrm{~m}$ & $315 \pm 213 \mathrm{~m}$ \\
\hline Atmospheric gases & \multirow{3}{*}{\multicolumn{3}{|c|}{$\begin{array}{c}<5 \mathrm{~m} \\
3.4 \pm 0.1 \%\left(\mathrm{O}_{4} \mathrm{SCD}\right)\end{array}$}} \\
\hline Atmospheric pressure $^{2}(\Delta \mathrm{P}=3 \%)$ & & & \\
\hline Instrument (shift: $0.02 \mathrm{~nm}$ ) & & & \\
\hline Total error & $1276 \mathrm{~m}$ & $846 \mathrm{~m}$ & $739 \mathrm{~m}$ \\
\hline
\end{tabular}

${ }^{1}$ Calculation results for the SSA decrease by $10 \% .{ }^{2}$ For the clear-sky calculation.

ocean is $1010.9 \pm 29.6(3 \sigma) \mathrm{hPa}$, seen from NCEP Reanalysis 2 data since 2004. In the clear-sky case, the difference of $\mathrm{O} 4 \mathrm{I}$ due to the $\pm 3 \%$ for pressure variation is $3.4 \pm 0.1 \%$ in all geometries.

Furthermore, the AEH error in terms of inaccurate spectral wavelength calibration is estimated based on the assumed errors of $\pm 0.02 \mathrm{~nm}$, which corresponds to 0.1 pixels for OMI. Although it is well known that the accuracy in the spectral wavelength calibration before the DOAS fitting affects the trace gas SCD retrieval, the errors in the O4I associated with the wavelength shift of the sub-pixel scale are estimated to be negligible due to the broad $\mathrm{O}_{4}$ absorption band width around $477 \mathrm{~nm}$.

Finally, the total error budget in the AEH retrieval is estimated based on the error analysis with respect to error sources. Note that the result of error analysis explains about $50 \%$ error for SSA and $25 \%$ error for the size parameter in calculating the total error budget. Overall, the total error budget in the AEH retrieval is estimated to be 739,1276 , and $846 \mathrm{~m}$ for the COPO, MITR, and WASO, respectively, with the exception of the contribution of the errors in the aerosol vertical profiles. Therefore, accurate assumption for optical properties of aerosol is essential to develop the retrieval algorithm of aerosol height.

\section{Case study}

To demonstrate the feasibility of real measurements, the AEHs are derived using hyperspectral data from OMI. OMI channels are composed of UV-1 (270-314 nm), UV-2 (306$380 \mathrm{~nm})$, and a visible wavelength range $(365-500 \mathrm{~nm})$ with a spectral resolution (FWHM) of $0.63,0.42$, and $0.63 \mathrm{~nm}$, respectively (Levelt et al., 2006). The spatial resolution is
$13 \mathrm{~km} \times 24 \mathrm{~km}$ at nadir in "global mode". In the present study, the OMI spectral data over the visible wavelength range are used to derive the $\mathrm{O} 4 \mathrm{I}$ at $477 \mathrm{~nm}$ and the $\mathrm{AEH}$ information.

Figure 12 shows an AEH retrieval algorithm for the case study. In retrieving AEH, AOD is obtained from the MODIS standard product (e.g., Levy et al., 2007). Although OMI aerosol product provides AOD at $500 \mathrm{~nm}$, AOD from OMI was partially affected by aerosol height and suffered from cloud contamination due to its large footprint (Torres et al., 2002). For this reason, AOD from MODIS was allocated to the OMI pixels as a reference AOD for the AEH retrieval. For type selection, the AE from MODIS and AI from OMI are used for the information of size and absorptivity, to classify aerosol into four types, following the method from Kim et al. (2007) and Lee et al. (2007). After determining AOD and aerosol type, LUT, which is generated as functions of geometries (SZA, VZA, and RAA), aerosol types and AODs, is used to determine the AEH information by comparing the simulated O4I value with the measured O4I value. The variables and their dimensions for the LUT calculations are listed in Table 7. Due to the limitation of the accuracy of aerosol type classification and the accuracy of AOD over land, this study estimates the AEH only over ocean surface. Although temporal and spatial variation of surface albedo influences the AEH result from the error study, surface albedo is assumed to be a fixed value of 0.10 , which is used in the sensitivity study. Even if the surface albedo is changed but known, the qualitative conclusion here is not affected. For the case study, the LUT of O4I is developed by the aerosol model based on AERONET data over East Asia. An extensive AERONET data set over East Asia is used to provide 
(a)

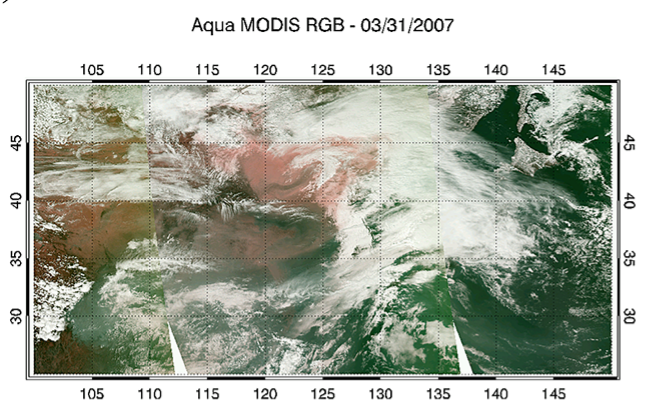

(c)

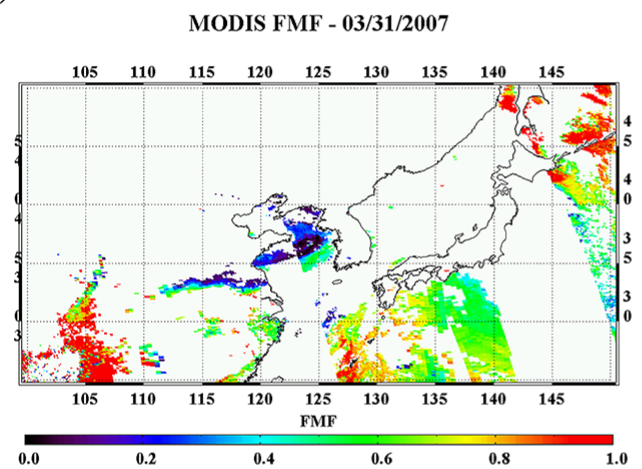

(b)

(d)

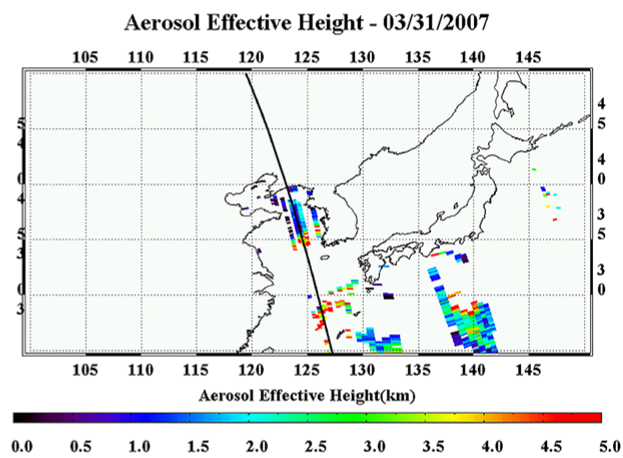

(e)

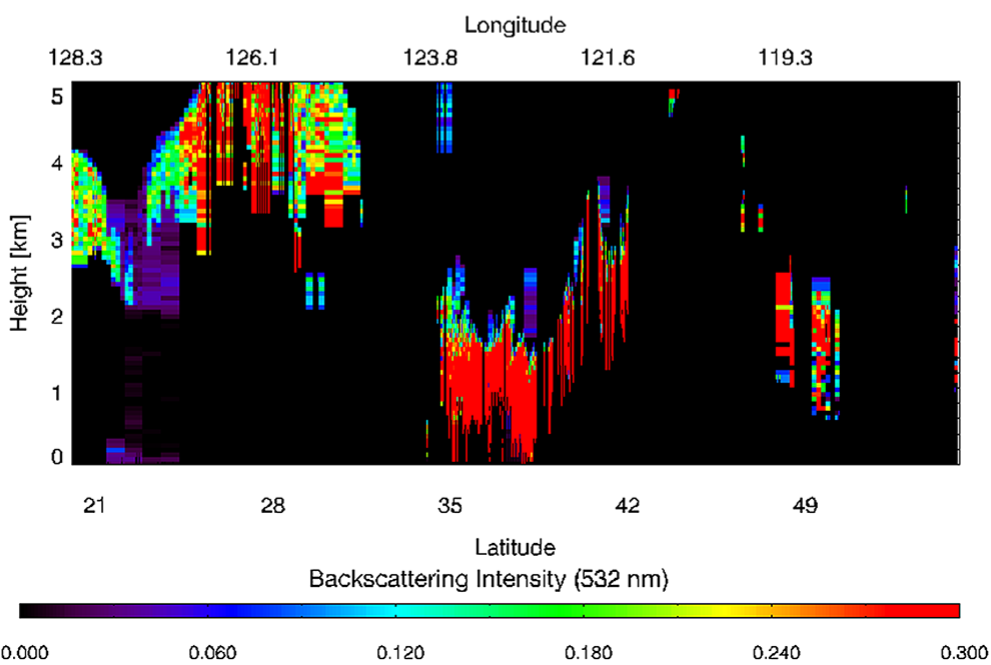

Figure 13. (a) MODIS RGB, (b) AOD, and (c) FMF; and (d) AEH distribution from OMI over East Asia; (e) backscattering intensity at $532 \mathrm{~nm}$ from CALIOP observations over the Yellow Sea on 31 March 2007.

representative aerosol optical properties for the LUT calculation.

Figure 13 shows the results of the retrieved AEH during the Asian dust event on 31 March 2007. MODIS products of AOD and FMF on this date show a thick dust layer with an AOD up to 1.0 from China to the Yellow Sea (Fig. 13b) and the FMF ranging from 0.2 to 0.4 , indicating the dominance of coarse-mode particles (Fig. 13c). Using the basis of the current algorithm with the predetermined AOD and type, the mean retrieved AEH is $2.3 \pm 1.3 \mathrm{~km}$ over 647 pixels in East Asia (Fig. 13d). The retrieved result is compared with the backscattering intensity from the CALIOP observations over the Yellow Sea as shown in Fig. 13e. From CALIOP observations, the aerosol layer height over the Yellow Sea is located at around $1 \mathrm{~km}$ altitude for most of observed regions. Over the Yellow Sea domain in $35-40^{\circ} \mathrm{N}$ and $120-130^{\circ} \mathrm{E}$, 
(a)

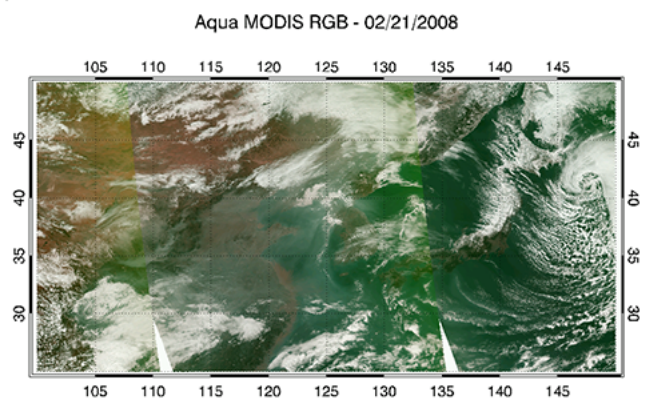

(c)

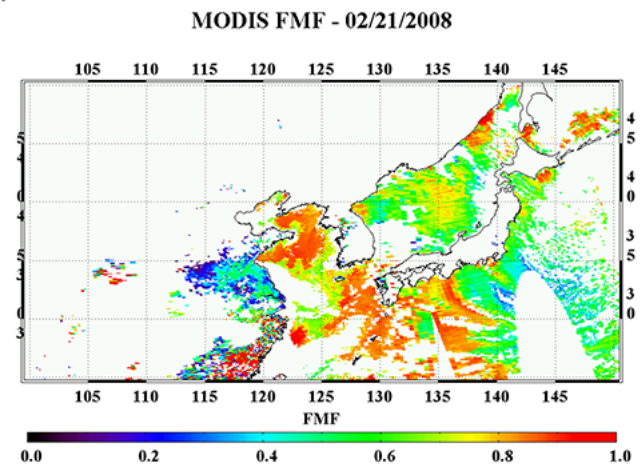

(b)

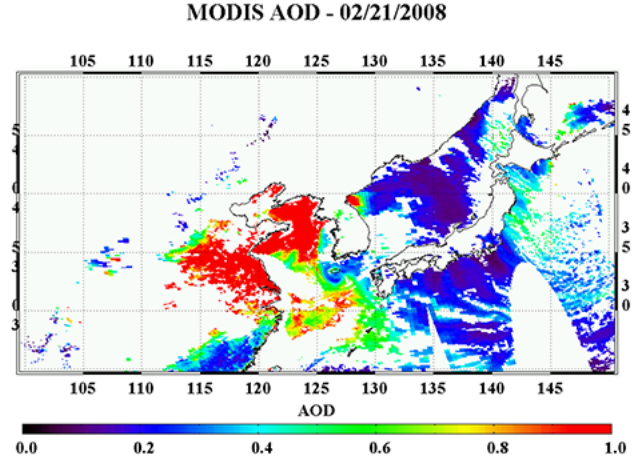

(d)

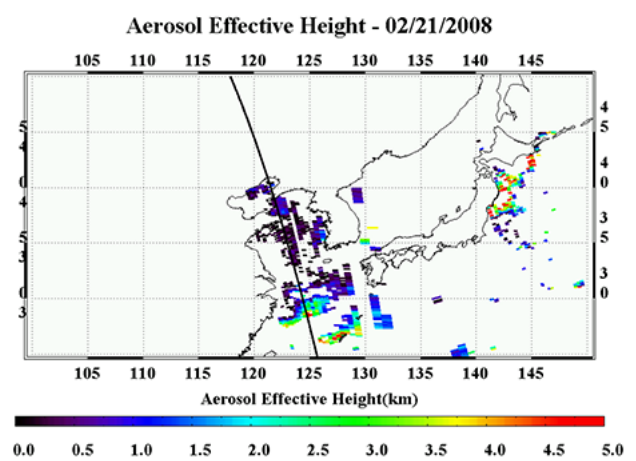

(e)

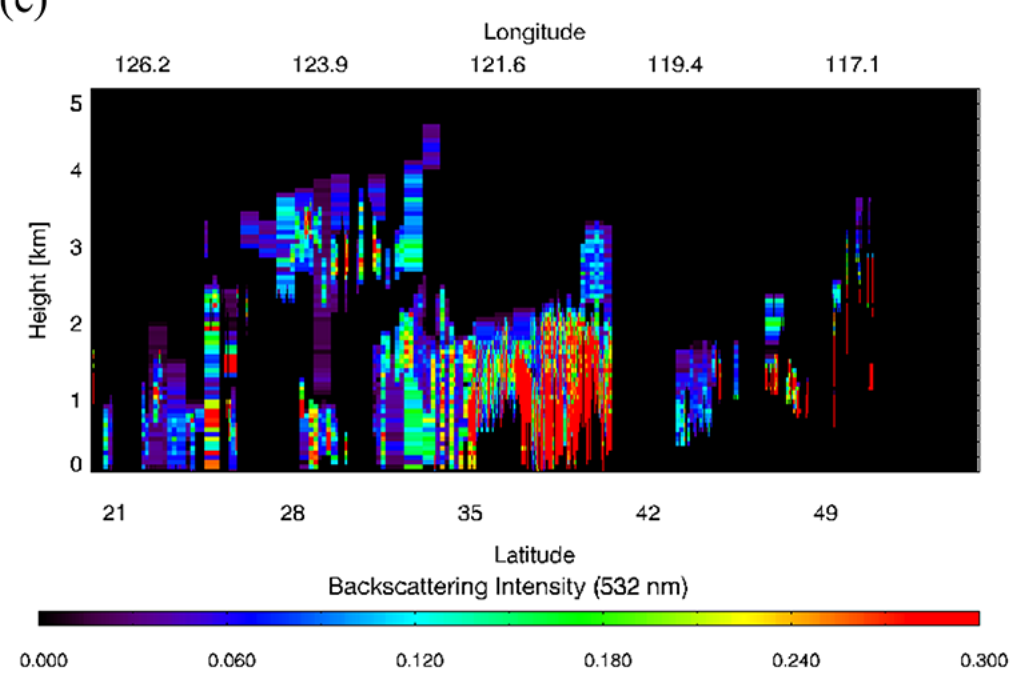

Figure 14. (a) MODIS RGB, (b) AOD, and (c) FMF; and (d) AEH distribution from OMI over East Asia; (e) backscattering intensity at $532 \mathrm{~nm}$ from CALIOP observations over the coastal region of China on 21 February 2008.

the AEH from OMI is $1.5 \pm 1.1 \mathrm{~km}$ over 166 pixels, which is within $1 \mathrm{~km}$ difference from the CALIOP. From the retrieved result, the retrieved $\mathrm{AEH}$ is successfully retrieved within the expected error, and the current algorithm quantitatively estimates the AEH over East Asia.

Figure 14 shows another case study of the retrieved AEH on 21 February 2008. MODIS products of AOD and FMF on this date show thick anthropogenic aerosol transported, with the AOD ranging from 0.6 to 1.0 (Fig. 14b) and the FMF ranging from 0.8 to 1.0 (Fig. 14c) all over the Yellow Sea. The mean retrieved AEH is $1.4 \pm 1.2 \mathrm{~km}$ over 1480 pixels in East Asia as shown in Fig. 14d. On this date, CALIOP passed over the coastal region between China and the Yellow Sea. The aerosol layer height ranged from 0.5 to $2.5 \mathrm{~km}$ during the overpass over East Asia as shown in Fig. 14e. The AEH from $\mathrm{OMI}$ is $0.6 \pm 0.4 \mathrm{~km}$ over 601 pixels in $30-40^{\circ} \mathrm{N}$ and 
Table 7. Dimensions of LUT for the AEH algorithm using OMI.

\begin{tabular}{lll}
\hline Variable name & No. of entries & Entries \\
\hline SZA & 7 & $0,10,20,30,40,50,60^{\circ}$ \\
VZA & 7 & $0,10,20,30,40,50,60^{\circ}$ \\
RAA & 10 & $0,20,40,60,80,100,120,140,160,180^{\circ}$ \\
AOD & 13 & $0.0,0.2,0.4,0.6,0.8,1.0,1.3,1.6,1.9,2.2,2.5,3.0,5.0$ \\
AEH & 16 & $0.0,1.0,1.2,1.4,1.6,1.8,2.0,2.2,2.4,2.6,2.8,3.0,3.5,4.0,5.0,10.0 \mathrm{~km}$ \\
Aerosol model & 3 & Dust, carbonaceous, non-absorbing (climatology over East Asia AERONET site) \\
\hline
\end{tabular}

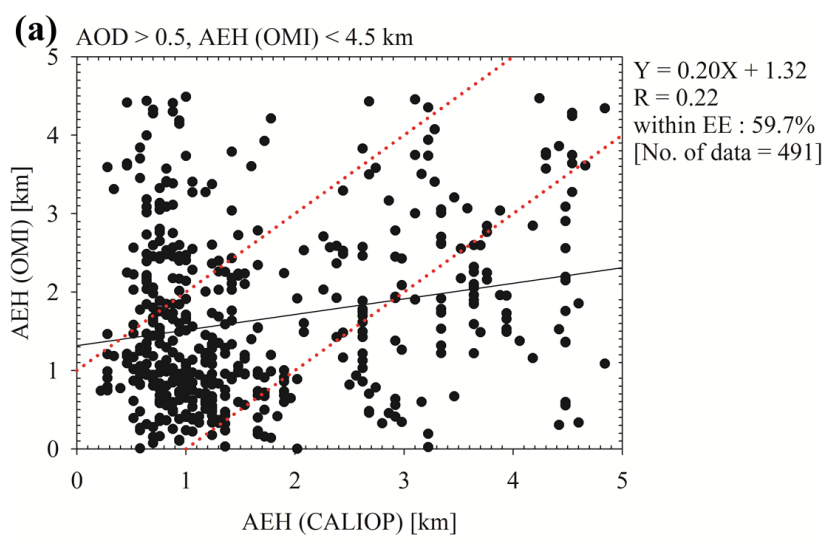

(b) $\mathrm{AOD}>1.0, \mathrm{AEH}(\mathrm{OMI})<4.5 \mathrm{~km}$

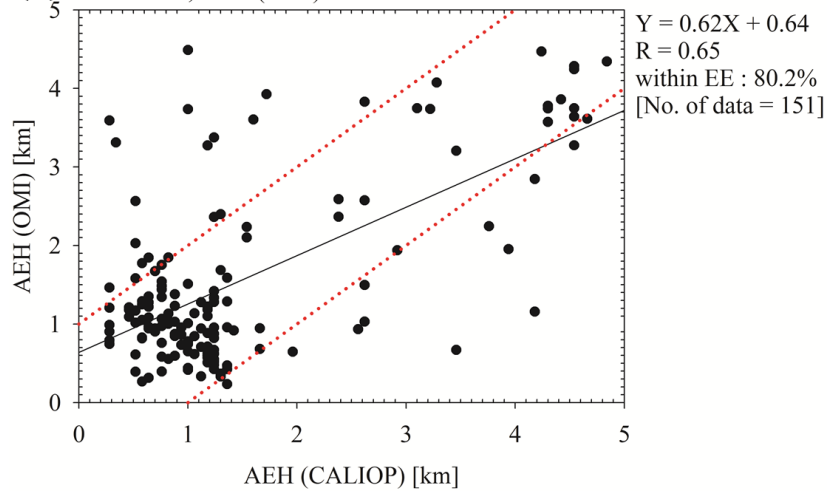

Figure 15. Comparison of AEH from OMI with CALIOP with (a) AOD > 0.5 and (b) AOD > 1.0 for aerosol transport cases in 2007 and 2008 over East Asia.

$120-125^{\circ}$ E. Contrary to large spatial variation of the AEH from CALIOP, the AEH from OMI shows spatially stable values on this date.

Figure 15 shows the scatter plot of AEH between CALIOP and OMI on the dates in Table 8, which lists aerosol transport cases over East Asia with simultaneous observations by OMI and CALIOP in 2007 and 2008. The AEH from CALIOP is estimated by the data from vertical profiles of aerosol extinction coefficient at $532 \mathrm{~nm}$. Because the O4I sensitivity for AEH is not large at AEHs higher than $4 \mathrm{~km}$, the comparison test was limited to cases with AEH less than $4.5 \mathrm{~km}$ from OMI. For data collocation, the latitude and longitude
Table 8. List of aerosol transport cases and their periods for comparison.

\begin{tabular}{ll}
\hline Case & Period \\
\hline 1 & 28 Mar-2 Apr 2007 \\
2 & 5-10 May 2007 \\
3 & 25-26 May 2007 \\
4 & 19-21 Feb 2008 \\
5 & 3-5 Apr 2008 \\
6 & 28-31 May 2008 \\
7 & 4-7 Dec 2008 \\
\hline
\end{tabular}

difference between two sensors is within $0.25^{\circ}$. Figure $15 \mathrm{a}$ shows the comparison of AEH from OMI and CALIOP with MODIS AOD larger than 0.5. It is assumed that the reference expected error (EE) is $1 \mathrm{~km}$ (Fishman et al., 2012). Almost $60 \%$ of retrieved pixels show the AEH result within the EE. Because of the large AEH error for low AOD, the accuracy of $\mathrm{AEH}$ result from OMI is poor. Furthermore, this case study assumes constant surface albedo value over ocean. However, ocean surface albedo is also changed by turbidity due to sediments and ocean surface due to wind. For this reason, the AEH error is exaggerated for low AOD cases. If the AOD for the comparison is set lower than 1.0, the proportion of pixel within EE improves up to $80 \%$ as shown in Fig. 15b. Furthermore, the correlation of the AEH between the two sensors is improved with the regression line slope of 0.62 and the correlation coefficient $(R)$ of 0.65 for thick aerosol layer cases. Therefore, the AEH algorithm from OMI provides reasonable information about the parameter of aerosol vertical distribution if an accurate aerosol model is provided for the forward radiative transfer model calculation.

\section{Summary and discussion}

The sensitivities of the O4I at $340,360,380$, and $477 \mathrm{~nm}$ bands are investigated with RTM calculations to derive the AEH using the space-borne hyperspectral data. Among these $\mathrm{O}_{4}$ absorption bands, the $\mathrm{O} 4 \mathrm{I}$ at $477 \mathrm{~nm}$ is considered to be suitable for the AEH retrieval. In addition to the AEH, AOD, aerosol type, aerosol vertical profile, particle size, and surface albedo are also found to have effects on the O4I at 
$477 \mathrm{~nm}$, while the spectral calibration and cross section of the atmospheric gases have negligible effects on the O4I. The major error source for the AEH retrieval is found to be the uncertainty in SSA, which leads to an AEH error ranging from 270 to $1400 \mathrm{~m}$ with an SSA perturbation of $10 \%$. In addition, the profile shape is also a major error source for the AEH estimation. According to the error estimations, the total errors are 739, 1276, and $846 \mathrm{~m}$ for absorbing, dust, and non-absorbing aerosol, respectively, due to combined uncertainties of the variation from AOD, SSA, particle size, and surface albedo.

In addition to the sensitivity analysis, an algorithm for the $\mathrm{AEH}$ derivation is developed for the first time based on a LUT that consists of the O4I in terms of the AEH, AOD, aerosol types, surface albedo, and measurement geometries. After the determination of AOD and aerosol types from the MODIS, the AEH value is derived over East Asia by the current algorithm using OMI measurement data. Considering the accuracy of AOD and aerosol types, the result is shown over ocean surface. From several cases for the long-range transport of aerosol over East Asia, the derived AEH shows reasonable value as compared to aerosol layer height from CALIOP with the correlation coefficient of 0.62 for an AOD larger than 1.0. In addition, $80 \%$ of estimated AEH from OMI showed an error of less than $1 \mathrm{~km}$ in $\mathrm{AEH}$.

There is much work to be done in improving the newly introduced algorithm as it requires the products from MODIS to determine the AOD and aerosol types prior to the AEH retrieval. The vertical distribution and the optical properties of the aerosol need to be quantified using a combination of observation databases, such as MPLNET and AERONET. Furthermore, the spatial variation of the AOD, surface pressure, and the contamination by the cloud on the sub-pixel scale need to be investigated as they are also thought to affect the retrieved results. If the surface reflectance can be characterized with sufficient accuracy, the retrieval of the AEH can be extended to over land. In addition, the O4I method in this study can be applied to the surface pressure estimation in clear regions.

Acknowledgements. This work was supported by the Eco Innovation Program of KEITI (grant no. 2012000160002), South Korea, and by the Brain Korea PLUS program.

Edited by: M. Van Roozendael

\section{References}

Accarreta, J. R., de Haan, J. F., and Stammes, P.: Cloud pressure retrieval using the $\mathrm{O}_{2}-\mathrm{O}_{2}$ absorption band at $477 \mathrm{~nm}$, J. Geophys. Res., 109, D05204, doi:10.1029/2003JD003915, 2004

Ahn, C., Torres, O., and Jethva, H.: Assessment of OMI near-UV aerosol optical depth over land, J. Geophys. Res., 119, 24572473, doi:10.1002/2013JD020188, 2014.
Albrecht, B. A.: Aerosols, cloud microphysics, and fractional cloudiness, Science, 245, 1227-1230, 1989.

Bogumil, K., Orphal, J., Burrows, J. P., and Flaud, J. M.: Vibrational progressions in the visible and near-ultraviolet absorption spectrum of ozone, Chem. Phys. Lett., 349, 241-248, 2001.

Castellanos, P., Boersma, K. F., Torres, O., and de Haan, J. F.: OMI tropospheric $\mathrm{NO}_{2}$ air mass factors over South America: effects of biomass burning aerosols, Atmos. Meas. Tech., 8, 3831-3849, doi:10.5194/amt-8-3831-2015, 2015.

Chiang, C.-W, Chen, W.-N., Liang, W.-A., Das, S. K., and Nee, J.B.: Optical properties of tropospheric aerosols based on measurements of lidar, sun-photometer and visibility at Chung-Li $\left(25^{\circ} \mathrm{N}\right.$, $\left.121^{\circ} \mathrm{E}\right)$, Atmos. Environ., 41, 4128-4137, 2007.

Chimot, J., Vlemmix, T., Veefkind, J. P., de Haan, J. F., and Levelt, P. F.: Impact of aerosols on the OMI tropospheric $\mathrm{NO}_{2}$ retrievals over industrialized regions: how accurate is the aerosol correction of cloud-free scenes via a simple cloud model?, Atmos. Meas. Tech. Discuss., 8, 8385-8437, doi:10.5194/amtd-88385-2015, 2015.

Chou, M.-D, Chan, P.-K., and Wang, M.: Aerosol radiative forcing derived from SeaWiFS-Retrieved aerosol optical properties, J. Atmos. Sci., 59, 748-757, 2002.

Christopher, S. A., Zhang, J., Kaufman, Y. J., and Remer, L. A.: Satellite-based assessment of top of atmosphere anthropogenic aerosol radiative forcing over cloud-free oceans, Geophys. Res. Lett, 33, L15816, doi:10.1029/2005GL025535, 2006.

Chu, D. A.: Analysis of the relationship between MODIS aerosol optical depth and PM, P. SPIE, 6299, 629903-629909, doi:10.1117/12.678841, 2006.

Chung, E. C., Ramanathan, V., Kim, D., and Podgorny. I. A.: Global anthropogenic aerosol direct forcing derived from satellite and ground-based observations, J. Geophys. Res., 110, D24207, doi:10.1029/2005JD006356, 2005.

Clémer, K., Van Roozendael, M., Fayt, C., Hendrick, F., Hermans, C., Pinardi, G., Spurr, R., Wang, P., and De Mazière, M.: Multiple wavelength retrieval of tropospheric aerosol optical properties from MAXDOAS measurements in Beijing, Atmos. Meas. Tech., 3, 863-878, doi:10.5194/amt-3-863-2010, 2010.

Curier, R. L., Veefkind, J. P., Braak, R., Veihelmann, B., Torres, O., and de Leeuw, G.: Retrieval of aerosol optical properties from OMI radiances using a multiwavelength algorithm: Application to western Europe, J. Geophys. Res., 113, D17S90, doi:10.1029/2007JD008738, 2008.

Dirksen, R. J., Boersma, K. F., de Laat, J., Stammes, P., van der Werf, G. R., Martin, M. V., and Kelder, H. M., An aerosol boomerang: Rapid around-the-world transport of smoke from the December 2006 Australian forest fires observed from space, J. Geophys. Res., 114, D21201, doi:10.1029/2009JD012360, 2009.

Dubovik, O., Holben, B., Eck, T. F., Smirnov, A., Kaufman, Y. J., King, M. D., Tanre, D., and Slutsker, I.: Variability of absorption and optical properties of key aerosol types observed in worldwide locations, J. Atmos. Sci., 59, 590-608, 2002.

Dubuisson, P., Frouin, R., Dessaily, D., Duforet, L., Leon, J.-F., Voss, K., and Antoine, D.: Estimating the altitude of aerosol plumes over the ocean from reflectance ratio measurements in the O2 A-band, Remote Sens. Environ., 113, 1899-1911, doi:10.1016/j.rse.2009.04.018, 2009. 
Fish, D. J. and Jones, R. L.: Rotational Raman scattering and the ring effect in zenith-sky spectra, Geophys. Res. Lett., 22, 811814, 1995.

Fishman, J., Iraci, L. T., Al-Saadi, J., Chance, K., Chavez, F., Chin, M., Coble, P., Davis, C., DiGiacomo, P. M., Edwards, D., Eldering, A., Goes, J., Herman, J., Hu, C., Jacob, D. J., Jordan, C., Kawa, S. R., Key, R., Liu, X., Lohrenz, S., Mannino, A., Natraj, V., Neil, D., Neu, J., Newchurch, M., Pickering, K., Salisbury, J., Sosik, H., Subramaniam, A., Tzortziou, M., Wang, J., and Wang, M.: The United States' Next Generation of Atmospheric Composition and Coastal Ecosystem Measurements: NASA's Geostationary Coastal and Air Pollution Events (GEO-CAPE) Mission, B. Am. Meteorol. Soc., 93, 1547-1566, 2012.

Friess, U., Monk, P. S., Remedios, J. J., Rozanov, A., Sinreich, R., Wagner, T., and Platt, U.: MAX-DOAS O4 measurements: A new technique to derive information on atmospheric aerosols: 2. Modeling studies, J. Geophys. Res., 111, D14203, doi:10.1029/2005JD006618, 2006.

Hayasaka, T., Satake, S., Shimizu, A., Sugimoto, N., Matsui, I., Aoki, K., and Muraji, Y.: Vertical distribution and optical properties of aerosols observed over Japan during the Atmospheric Brown Clouds-East Asia Regional Experiment 2005, J. Geophys. Res., 112, D22S35, doi:10.1029/2006JD008086, 2007.

Haywood, J. M. and Shine, K. P.: The effect of anthropogenic sulfate and soot aerosol on the clear sky planetary radiation budget, Geophys. Res. Lett., 22, 603-606, 1995.

Herman, J. R., Bhartia, P. K., Torres, O., Hsu, C., Seftor, C., and Celarier, E.: Global distribution of UV-absorbing aerosols from Nimbus-7/TOMS data, J. Geophys. Res., 102, 16911-16922, 1997.

Hermans, C., Vandaele, A. C., Carleer, M., Fally, S., Colin, R., Jenouvrier, A., Coquart, B., and Merienne, M.: Absorption Crosssections of atmospheric constituents: $\mathrm{NO}_{2}, \mathrm{O}_{2}$, and $\mathrm{H}_{2} \mathrm{O}$, Environ. Sci. Pollut. Res., 6, 151-158, 1999.

Hermans, C., Vandaele, A. C., Fally, S., Carleer, M., Colin, R., Coquart, B., Jenouvrier, A., and Merienne, M. F.: Absorption crosssection of the collision-induced bands of oxygen from the UV to the NIR. In Weakly interacting molecular pairs: unconventional absorbers of radiation in the atmosphere, Springer, the Netherlands, 193-202, 2003.

Hess, M., Koepke, P., and Schult, I.: Optical properties of aerosols and clouds: The software package OPAC, B. Am. Meteorol. Soc., 79, 831-844, 1998.

Higurashi, A. and Nakajima, T.: Detection of aerosol types over the East China Sea near Japan from four-channel satellite data, Geophys. Res. Lett., 29, 1836, doi:10.1029/2002GL015357, 2002.

Holzer-Popp, T. and Schroedter-Homscheidt, M.: Synergetic aerosol retrieval from ENVISAT, Proc. ERS/ENVISAT Symposium, Salzburg, Vol. 6, No. 10.9, 2004.

Hutchison, K. D., Smith, S., and Faruqui, S. J.: Correlating MODIS aerosol optical thickness data with ground-based $\mathrm{PM}_{2.5}$ observations across Texas for use in a real-time air quality prediction system, Atmos. Environ., 39, 7190-7203, 2005.

Irie, H., Kanaya, Y., Akimoto, H., Iwabuchi, H., Shimizu, A., and Aoki, K.: Dual-wavelength aerosol vertical profile measurements by MAX-DOAS at Tsukuba, Japan, Atmos. Chem. Phys., 9, 2741-2749, doi:10.5194/acp-9-2741-2009, 2009.

Irie, H., Takashima, H., Kanaya, Y., Boersma, K. F., Gast, L., Wittrock, F., Brunner, D., Zhou, Y., and Van Roozendael, M.: Eight- component retrievals from ground-based MAX-DOAS observations, Atmos. Meas. Tech., 4, 1027-1044, doi:10.5194/amt-41027-2011, 2011.

Irie, H., Nakayama, T., Shimizu, A., Yamazaki, A., Nagai, T., Uchiyama, A., Zaizen, Y., Kagamitani, S., and Matsumi, Y.: Evaluation of MAX-DOAS aerosol retrievals by coincident observations using CRDS, lidar, and sky radiometer inTsukuba, Japan, Atmos. Meas. Tech., 8, 2775-2788, doi:10.5194/amt-82775-2015, 2015.

Jeong, M.-J., and Hsu, N. C.: Retrievals of aerosol single-scattering albedo and effective aerosol layer height for biomass-burning smoke: Synergy derived from "A-Train" sensors, Geophys. Res. Lett., 35, L24801, doi:10.1029/2008GL036279, 2008.

Jethva, H., Torres, O., and Ahn, C.: Global assessment of OMI aerosol single-scattering albedo using ground-based AERONET inversion, J. Geophys. Res., 119, 9020-9040, doi:10.1002/2014JD021672, 2014.

Johnson, B. T., Heese, B., McFarlane, S. A., Chazette, P., Jones, A., and Bellouin, N.: Vertical distribution and radiative effects of mineral dust and biomass burning aerosol over West Africa during DABEX, J. Geophys. Res., 113, D00C12, doi:10.1029/2008JD009848, 2008.

Jones, A., Roberts, D. L., and Slingo, A.: A climate model study of indirect radiative forcing by anthropogenic sulphate aerosols, Nature, 370, 450-453, 1994.

Jones, T. A. and Christopher, S. A.: MODIS derived fine mode fraction characteristics of marine, dust, and anthropogenic aerosols over the ocean, constrained by GOCART, MOPITT, and TOMS, J. Geophys. Res., 112, D22204, doi:10.1029/2007JD008974, 2007.

Kaufman, Y. J., Tanre, D., and Boucher, O.: A satellite view of aerosols in the climate system, Nature, 419, 215-223, 2002.

Kim, J., Lee, J., Lee, H. C., Higurashi, A., Takemura, T., and Song, C. H.: Consistency of the aerosol type classification from satellite remote sensing during the Atmospheric Brown Cloud - East Asia Regional Experiment campaign, J. Geophys. Res., 112, D22S33, doi:10.1029/2006JD008201, 2007.

Kleipool, Q. L., Dobber, M. R., de Haan, J. F., and Levelt, P. F.: Earth surface reflectance climatology from 3 years of OMI data, J. Geophys. Res., 113, D18308, doi:10.1029/2008JD010290, 2008.

Koelemeijer, R. B. A., de Haan, J. F., and Stammes, P.: A database of spectral surface reflectivity in the range 335-772 nm derived from 5.5 years of GOME observations, J. Geophys. Res., 108, 4070, doi:10.1029/2002JD002429, 2003.

Kokhanovsky, A. A. and Rozanov, V. V.: The determination of dust cloud altitudes from a satellite using hyperspectral measurements in the gaseous absorption band, Int. J. Remote. Sens., 31, 27292744, 2010.

Koppers, G. A. A. and Murtagh, D. P.: Retrieval of height resolved aerosol optical thickness in the atmospheric band (Chapter 5), in: Radiative transfer in the absorption bands of oxygen: Studies of their significance in ozone chemistry and potential for aerosol remote sensing, edited by: Koppers, G. A. A., Stockholm University, Stockholm, Sweden, 1997.

Labonne, M., Breon, F.-M., and Chevallier, F.: Injection height of biomass burning aerosols as seen from a spaceborne lidar, Geophys. Res. Lett., 34, L11806, doi:10.1029/2007GL029311, 2007. 
Lee, H., Irie, H., Kim, Y. J., Noh, Y., Lee, C., Kim, Y., and Chun, K. J.: Retrieval of aerosol extinction in the lower troposphere based on UV MAX-DOAS measurements, Aerosol Sci. Tech., 43, 502$509,2009$.

Lee, H., Irie, H., Gu, M., Kim, J., and Hwang, J.: Remote sensing of tropospheric aerosol using UV MAX-DOAS during hazy conditions in winter: Utilization of $\mathrm{O}_{4}$ absorption bands at wavelength intervals of 338-368 and 367-393 nm, Atmos. Environ., 45, 5760-5769, doi:10.1016/j.atmosenv.2011.07.019, 2011

Lee, J., Kim, J., Lee, H. C., and Takemura, T.: Classification of aerosol type from MODIS and OMI over East Asia, Asia-Pac. J. Atmos. Sci., 43, 343-357, 2007.

Lee, J., Kim, J., Song, C. H., Ryu, J.-H., Ahn, Y.-H., and Song, C. K.: Algorithm for retrieval of aerosol optical properties over the ocean from the Geostationary Ocean Color Imager, Remote Sens. Environ., 114, 1077-1088, 2010.

Levelt, P. F., van den Oord, G. H. J., Dobber, M. R., Maelkki, A., Visser, H., de Vries, J., Stammes, P., Lundell, J. O. V., and Saari, H.: The Ozone Monitoring Instrument, IEEE T. Geosci. Remote., 44, 1093-1101, 2006.

Levy, R. C., Remer, L. A., Mattoo, S., Vermote, E. F., and Kaufman, Y. J.: Second-generation operational algorithm : Retrieval of aerosol properties over land from inversion of Moderate Resolution Imaging Spectroradiometer spectral reflectance, J. Geophys. Res., 112, D13211, doi:10.1029/2006JD007811, 2007.

Li, X., Brauers, T., Shao, M., Garland, R. M., Wagner, T., Deutschmann, T., and Wahner, A.: MAX-DOAS measurements in southern China: retrieval of aerosol extinctions and validation using ground-based in-situ data, Atmos. Chem. Phys., 10, 20792089, doi:10.5194/acp-10-2079-2010, 2010.

Lin, J.-T., Martin, R. V., Boersma, K. F., Sneep, M., Stammes, P., Spurr, R., Wang, P., Van Roozendael, M., Clémer, K., and Irie, H.: Retrieving tropospheric nitrogen dioxide from the Ozone Monitoring Instrument: effects of aerosols, surface reflectance anisotropy, and vertical profile of nitrogen dioxide, Atmos. Chem. Phys., 14, 1441-1461, doi:10.5194/acp-14-1441-2014, 2014.

Lin, J.-T., Liu, M.-Y., Xin, J.-Y., Boersma, K. F., Spurr, R., Martin, R., and Zhang, Q.: Influence of aerosols and surface reflectance on satellite $\mathrm{NO}_{2}$ retrieval: seasonal and spatial characteristics and implications for $\mathrm{NO}_{x}$ emission constraints, Atmos. Chem. Phys., 15, 11217-11241, doi:10.5194/acp-15-11217-2015, 2015.

Liu, Y., Sarnat, J. A., Kilaru, V., Jacob, D. J., and Koutrakis, P.: Estimating ground-level $\mathrm{PM}_{2.5}$ in the Eastern United States using satellite remote sensing, Environ. Sci. Technol., 39, 3269-3278, 2005.

Nakajima, T. and Higurashi, A.: A use of two-channel radiances for and aerosol characterization from space, Geophys. Res. Lett., 25, 3815-3818, 1998.

Newnham, D. A. and Ballard, J.: Visible absorption cross sections and integrated absorption intensities of molecular oxygen $\left(\mathrm{O}_{2}\right.$ and $\mathrm{O}_{4}$ ), J. Geophys. Res., 103, 28801-28816, 1998.

Omar, A. H., Winker, D. M., Kittaka, C., Vaughan, M. A., Liu, Z., Hu, Y., Trepte, C. R., Rogers, R. R., Ferrare, R. A., Lee, K.-P., Kuehn, R. E., and Hostetler, C. A.: The CALIPSO automated aerosol classification and lidar ratio selection algorithm, J. Atmos. Ocean. Tech., 26, 1994-2014, 2009.

Payne, R. E.: Albedo of the Sea Surface, J. Atmos. Sci., 29, 959970, 1972.
Platt, U.: Differential optical absorption spectroscopy (DOAS), Air Monitoring by Spectroscopic Technique, 127, 27-84, 1994.

Platt, U. and Stutz, J.: Differential absorption spectroscopy, Springer, Berlin, Heidelberg, 2008.

Prospero, J. M.: Long-term measurements of the transport of African mineral dust to the southeastern United States: Implications for regional air quality, J. Geophys. Res., 104, 1591715927, 1999.

Reid, J. S., Westphal, D. L., Livingston, J. M., Savoie, D. L., Maring, H. B., Jonsson, H. H., Eleuterio, D. P., Kinney, J. E., and Reid, E. A.: Dust vertical distribution in the Caribbean during the Puerto Rico Dust Experiment, Geophys. Res. Lett., 29, 1151, doi:10.1029/2001GL014092, 2002.

Remer, L. A., Kleidman, R. G., Levy, R. C., Kaufman, Y. J., Tanre, D., Mattoo, S., Martins, J. V., Ichoku, C., Koren, I., Yu, H., and Holben, B. N.: Global aerosol climatology from the MODIS satellite sensors, J. Geophys. Res., 113, D14S07, doi:10.1029/2007JD009661, 2008.

Sanders, A. F. J. and de Haan, J. F.: Retrieval of aerosol parameters from the oxygen A band in the presence of chlorophyll fluorescence, Atmos. Meas. Tech., 6, 2725-2740, doi:10.5194/amt-62725-2013, 2013.

Sanders, A. F. J., de Haan, J. F., Sneep, M., Apituley, A., Stammes, P., Vieitez, M. O., Tilstra, L. G., Tuinder, O. N. E., Koning, C. E., and Veefkind, J. P.: Evaluation of the operational Aerosol Layer Height retrieval algorithm for Sentinel-5 Precursor: application to $\mathrm{O}_{2} \mathrm{~A}$ band observations from GOME-2A, Atmos. Meas. Tech., 8, 4947-4977, doi:10.5194/amt-8-4947-2015, 2015.

Sanghavi, S., Martonchik, J. V., Landgraf, J., and Platt, U.: Retrieval of the optical depth and vertical distribution of particulate scatterers in the atmosphere using $\mathrm{O}_{2}$ A- and B-band SCIAMACHY observations over Kanpur: a case study, Atmos. Meas. Tech., 5, 1099-1119, doi:10.5194/amt-5-1099-2012, 2012.

Sasano, Y.: Tropospheric aerosol extinction coefficient profiles derived from scanning lidar measurements over Tsukuba, Japan, from 1990 to 1993, Appl. Opt., 35, 4941-4952, 1996.

Seo, S., Kim, J., Lee, H., Jeong, U., Kim, W., Holben, B. N., Kim, S.-W., Song, C. H., and Lim, J. H.: Estimation of $\mathrm{PM}_{10}$ concentrations over Seoul using multiple empirical models with AERONET and MODIS data collected during the DRAGON-Asia campaign, Atmos. Chem. Phys., 15, 319-334, doi:10.5194/acp-15-319-2015, 2015.

Shimizu, A., Sugimoto, N., Matsui, I., Arao, K., Uno, I., Murayama, T., Kagawa, N., Aoki, K., Uchiyama, A., and Yamazaki, A.: Continuous observation of Asian dust and other aerosols by polarization lidars in China and Japan during ACE-Asia, J. Geophys. Res., 109, D19S17, doi:10.1029/2002JD003253, 2004.

Sneep, M., de Haan, J. F., Stammes, P., Wang, P., Vanbauce, C., Joiner, J., Vasilkov, A. P., and Levelt, P. F.: Three-way comparison between OMI and PARASOL cloud pressure products, J. Geophys. Res., 113, D15S23, doi:10.1029/2007JD008694, 2008.

Spurr, R. and Christi, M.: On the generation of atmospheric property Jacobians from the (V)LIDORT linearized radiative transfer models, J. Quant. Spectrosc. Ra., 142, 109-115, 2014.

Spurr, R. J. D.: Simultaneous derivation of intensities and weighting functions in a general pseudo-spherical discrete ordinate radiative transfer treatment, J. Quant. Spectro. Rad. Trans., 75, 129_ $175,2002$. 
Spurr, R. J. D.: VLIDORT: A linearized pseudo-spherical vector discrete ordinate radiative transfer code for forward model and retrieval studies in multilayer multiple scattering media, J. Quant. Spectrosc. Ra., 102, 316-342, 2006.

Spurr, R. J. D., Kurosu, T. P., and Chance, K. V.: A linearized discrete ordinate radiative transfer model for atmospheric remotesensing retrieval, J. Quant. Spectro. Rad. Trans., 68, 689-735, 2001.

Stutz, J. and Platt, U.: Numerical analysis and estimation of the statistical error of differential optical absorption spectroscopy measurements with least-squares methods, Appl. Optics, 35, 30, 6041-6053, 1996.

Torres, O., Bhartia, P. K., Herman, J. R., Ahmad, Z., and Gleason, J.: Derivation of aerosol properties from satellite measurements of backscattered ultraviolet radiation: Theoretical basis, J. Geophys. Res., 103, 17099-17110, 1998.

Torres, O., Decae, R., Veefkind, P., and de Leeuw, G.: OMI Aerosol Retrieval Algorithm, OMI Algorithm Theoretical Basis Document, Vol. III, Clouds, Aerosols and Surface UV Irradiance, NASA-KNMI ATBD-OMI-03, 47-71, 2002.

Torres, O., Bhartia, P. K., Sinyuk, A., Welton, E. J., and Holben, B. N.: Total Ozone Mapping Spectrometer measurements of aerosol absorption from space: Comparison to SAFARI 2000 ground-based observations, J. Geophys. Res., 110, D10S18, doi:10.1029/2004JD004611, 2005.

Torres, O., Tanskanen, A., Veihelmann, B., Ahn, C., Braak, R., Bhartia, P. K., Veefkind, P., and Levelt, P.: Aerosols and surface UV products from Ozone Monitoring Instrument observations: An overview, J. Geophys. Res., 112, D24S47, doi:10.1029/2007JD008809, 2007.

Twomey, S. A., Piepgrass, M., and Wolfe, T. L.: An assessment of the impact of pollution on the global albedo, Tellus, 36, 356-366, 1984.

United States Committee on Extension to the Standard Atmosphere: US Standard Atmosphere 1976, National Oceanic and Atmospheric Administration, NASA, United States Air Force, Washington D.C., USA, 1976.

Vandaele, A. C., Hermans, C., Simon, P. C., Carleer, M., Colin, R., Fally, S., Merienne, M. F., Jenouvrier, A., and Coquart, B.: Measurements of the $\mathrm{NO}_{2}$ absorption cross-section from 42000 $\mathrm{cm}^{-1}$ to $10000 \mathrm{~cm}^{-1}(238-1000 \mathrm{~nm})$ at $220 \mathrm{~K}$ and $294 \mathrm{~K}, \mathrm{~J}$. Quant. Spectrosc. Ra., 59, 171-184, 1998.

van Roozendael, M. and Fayt, C.: WinDOAS 2.1 Software user manual, Uccle, IASB/BIRA, 2001.

Veefkind, J. P., de Leeuw, G., Durkee, P. A., Russell, P. B., Hobbs, P. V., and Livingston, J. M.: Aerosol optical depth retrieval using ATSR-2 and AVHRR data during TARFOX, J. Geophys. Res., 104, 2253-2260, 1999.
Veihelmann, B., Levelt, P. F., Stammes, P., and Veefkind, J. P.: Simulation study of the aerosol information content in OMI spectral reflectance measurements, Atmos. Chem. Phys., 7, 3115-3127, doi:10.5194/acp-7-3115-2007, 2007.

Wagner, T., Dix, B., Friedeburg, C. V., Friess, U., Sanghavi, S., Sinreich, R., and Platt, U.: MAX-DOAS $\mathrm{O}_{4}$ measurements: A new technique to derive information on atmospheric aerosols- Principles and information content, J. Geophys. Res., 109, D22205, doi:10.1029/2004JD004904, 2004.

Wagner, T., Beirle, S., Deutschmann, T., Grzegorski, M., and Platt, U.: Satellite monitoring of different vegetation types by differential optical absorption spectroscopy (DOAS) in the red spectral range, Atmos. Chem. Phys., 7, 69-79, doi:10.5194/acp-7-692007, 2007.

Wagner, T., Deutschmann, T., and Platt, U.: Determination of aerosol properties from MAX-DOAS observations of the Ring effect, Atmos. Meas. Tech., 2, 495-512, doi:10.5194/amt-2-4952009, 2009.

Wagner, T., Beirle, S., Deutschmann, T., and Penning de Vries, M.: A sensitivity analysis of Ring effect to aerosol properties and comparison to satellite observations, Atmos. Meas. Tech., 3, 1723-1751, doi:10.5194/amt-3-1723-2010, 2010.

Wang, J. and Christopher, S. A.: Intercomparison between satellitederived aerosol optical thickness and $\mathrm{PM}_{2.5}$ mass: Implications for air quality studies, Geophys. Res. Lett., 30, 2095, doi:10.1029/2003GL018174, 2003.

Wang, P., Tuinder, O. N. E., Tilstra, L. G., de Graaf, M., and Stammes, P.: Interpretation of FRESCO cloud retrievals in case of absorbing aerosol events, Atmos. Chem. Phys., 12, $9057-$ 9077, doi:10.5194/acp-12-9057-2012, 2012.

Watson, J. G., Chow, J. C., Lu, Z., Fujita, E. M., Lowenthal, D. H., Lawson, D. R., and Ashbaugh, L. L.: Chemical mass balance source apportionment of PM10 during the Southern California air quality study, Aerosol Sci. Tech., 21, 1-36, 1994.

Yang, K., Liu, X., Bhartia, P. K., Krotkov, N. A., Carn, S. A., Hughes, E. J., Krueger, A. J., Spurr, R. J. D., and Trahan, S. G.: Direct retrieval of sulfur dioxide amount and altitude from spaceborne hyperspectral UV measurements: Theory and application, J. Geophys. Res., 115, D00L09, doi:10.1029/2010JD013982, 2010.

Zhang, H., Lyapustin, A., Wang, Y., Kondragunta, S., Laszlo, I., Ciren, P., and Hoff, R. M.: A multi-angle aerosol optical depth retrieval algorithm for geostationary satellite data over the United States, Atmos. Chem. Phys., 11, 11977-11991, doi:10.5194/acp11-11977-2011, 2011. 